\title{
MASTER
}

\section{INVESTIGATION OF THE CHEMISTRY OF CALCIUM CARBONATE SCALE NUCLEATION AND GROWTH FROM SEAWATER ON OTEC HEAT EXCHANGERS}

John W. Morse, Garrett W. Brass,

Lynn M. Walter, and Reed Van Valin

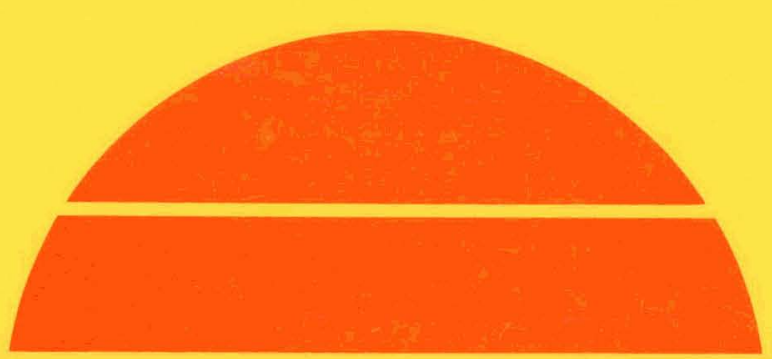

Argonne National Laboratory 9700 South Cass Avenue Argonne, Illinois 60439

Prepared for the

U. S. Department of Energy Division of Central Solar Technology under Contract W-31-109-Eng-38 


\section{DISCLAIMER}

This report was prepared as an account of work sponsored by an agency of the United States Government. Neither the United States Government nor any agency Thereof, nor any of their employees, makes any warranty, express or implied, or assumes any legal liability or responsibility for the accuracy, completeness, or usefulness of any information, apparatus, product, or process disclosed, or represents that its use would not infringe privately owned rights. Reference herein to any specific commercial product, process, or service by trade name, trademark, manufacturer, or otherwise does not necessarily constitute or imply its endorsement, recommendation, or favoring by the United States Government or any agency thereof. The views and opinions of authors expressed herein do not necessarily state or reflect those of the United States Government or any agency thereof. 


\section{DISCLAIMER}

Portions of this document may be illegible in electronic image products. Images are produced from the best available original document. 
The facilities of Argonne National Laboratory are owned by the United States Government. Under the terms of a contract (W-31-109-Eng-38) among the U. S. Department of Energy, Argonne Universities Association and The University of Chicago, the University employs the staff and operates the Laboratory in accordance with policies and programs formulated, approved and reviewed by the Association.

\section{MEMBERS OF ARGONNE UNIVERSITIES ASSOCIATION}

The University of Arizona

Carnegie-Mellon University

Case Western Reserve University

The University of Chicago

University of Cincinnati

Illinois Institute of Technology

University of Illinois

Indiana University

The University of Iowa

Iowa State University
The University of Kansas

Kansas State University

Loyola University of Chicago

Marquette University

The University of Michigan

Michigan State University

University of Minnesota

University of Missouri

Northwestern University

University of Notre Dame
The Ohio State University

Ohio University

The Pennsylvania State University

Purdue University

Saint Louis University

Southern Illinois University

The University of Texas at Austin

Washington University

Wayne State University

The University of Wisconsin-Madison

\section{NOTICE}

This report was prepared as an account of work sponsored by an agency of the United States Government. Neither the United States nor any agency thereof, nor any of their employees, makes any warranty, expressed or implied, or assumes any legal liability or responsibility for any third party's use or the results of such use of any information, apparatus, product or process disclosed in this report, or represents that its use by such third party would not infringe privately owned rights. Mention of commercial products, their manufacturers, or their suppliers in this publication does not imply or connote approval or disapproval of the product by Argonne National Laboratory or the United States Government.

Printed in the United States of America

Available from

National Technical Information Service

U. S. Department of Commerce

5285 Port Royal Road

Springfield, VA 22161

NTIS price codes

Printed copy: A05

Microfiche copy: A01 
John W. Morse, Garrett W. Brass, Lynn M. Walter, and Reed Van Valin

Rosenstiel School of Marine and Atmospheric Science University of Miami 4600 Rickenbacker Causeway Miami, Florida 33149

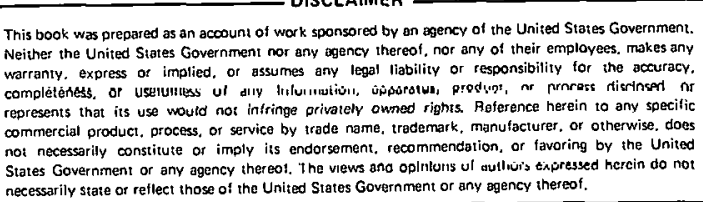

August 1979 


\section{THIS PAGE}

\section{WAS INTENTIONALLY LEFT BLANK}


EXECUTIVE SUMMARY . . . . . . . . . . . . . . . . . . . 1

ABSTRACT . . . . . . . . . . . . . . . . . . . . . 3

I. INTRODUCTION . . . . . . . . . . . . . . . . . . 3

II. GOME II INORGANIC SCALE CHEMISTRY . . . . . . . . . . . 4

A. Summary . . . . . . . . . . . . . . . . . 4

B. Introduction ................ 5

C. Pipe Surface Chemistry Analytic Procedure . . . . . 5

D. Results ................... . 6

E. Discussion . . . . . . . . . . . . . . 11

III. CALCITE AND ARAGONITE POWDER GROWTH RATE TESTS . • . . . 12

A. Summary . . . . . . . . . . . . . . 12

B. Introduction . . . . . . . . . . . . . 12

C. Test Procedures ................. 13

D. Results ... . . . . . . . . . . . . . . 14

E. Discussion . . . . . . . . . . . . . . 21

IV. LIQUID AMMONIA INDUCED SCALE DEPOSITION . . . . . . . . 21

A. Summary . . . . . . . . . . . . . . . . 21

B. Introduction . . . . . . . . . . . . . . 22

C. Test Procedures and Results . . . . . . . . . 22

1. Glass Tube Tests . . . . . . . . . . . 22

2. Tube Aging Tests . . . . . . . . . . . . 25

3. Ammonia Injection Tests . . . . . . . . . . 27

4. SEM Observations ............. . . 38

D. Conclusions . . . . . . . . . . . . . . . 43

V. STAGNANT SEAWATER ṄUCLEATION TESTS . . . . . . . . . . 46

A. Summary . . . . . . . . . . . . . . . . 46

B. Introduction .................... 47

C. Test Procedures ................ . 47

D. Kesults . . . . . . . . . . . . . 48

ACKNOWLEDGEMENTS . . . . . . . . . . . . . . . . . . 67

BIBLIOGRAPHY . . . . . . . . . . . . . . . . . . 68 


\section{LIST OF FIGURES}

No.

$\underline{\text { Title }}$

$\underline{\text { Page }}$

1. The $\log$ of the rate of powder growth versus the $\log$ of

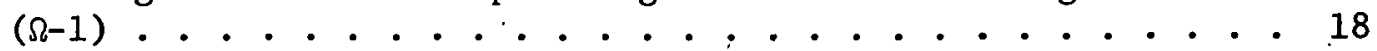

2. Scale streak formed on glass tube . . . . . . . . . . 26

3. Liquid ammonia leak testing apparatus . . . . . . . . . 28

4. Tube sectioning scheme . . . . . . . . . . . . 32

5. Injection region of tuhe B-9.............. 33

6. Injection region of tube $\overline{\mathrm{B}}-1$. . . . . . . . . . . . 34

7. Down stream sections of tubes B-4 and B-9 . . . . . . . 35

8. Liquid ammonia induced scale composition . . . . . . . . 40

9. SEM Picture of "aged" copper-nickel tube surface after.

liquid ammonia injection ................ 41

10. SEM picture of "aged" stainless steel tube surface after

liquid ammonia injection .. . . . . . . . . . . 42

1.1. SEM picture of "aged" titanium tube surface after

liquid ammonia injection . . . . . . . . . . . . . 44

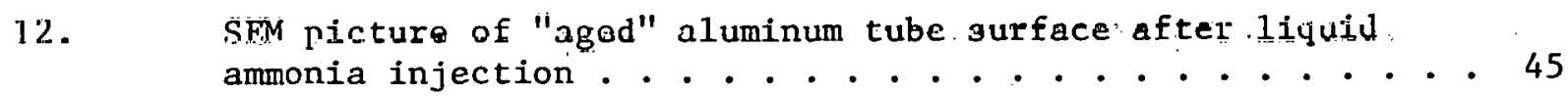

13. Stagnant $\mathrm{CaCO}_{3}$ nucleation tests . . . . . . . . . 51

14. Dissolved Al concentrations in seawater exposed to $\quad$ Al tubes .... 57

15. The concentration of A1 nn A1. twhe surfaces
a. Exposure at $22^{\circ} \mathrm{C}$ b. Exposure at $3^{\circ} \mathrm{C}$. . . . . . 60

16. SEM pictures of $\mathrm{Al}$ and $\mathrm{Cu}-\mathrm{Ni}$ tube surfaces after exposure.

to stagnant seawater ................. 62

17. SEM pictures of SS and Ti tube surfaces after exposure
to stagnant seawater . . . . . . . . . . . . 63

18. Calcium and magnesium on Al tube surfaces . . . . . . . . 66 


\section{LIST OF TABLES}

No.

Title

Page

1. Sample Information . . . . . . . . . . . . . . . . 7

2. Absolute Surface Concentrations . . . . . . . . . . . 8

3. Blank Corrected Surface Concentrations . . . . . . . . . 9

4. Calcium and Magnesium Relations . . . . . . . . . . 10

5. Calcite and Aragonite Powder Growth Test Data . . . . . 15

6. Reaction Equation Parameters .............. 19

7. Influence of Nutrients on Growth Rate . . . . . . . . . 20

8. Results of Glass Tube Tests . . . . . . . . . . . . 24

9. Metal Tube Test Parameters . . . . . . . . . . . . 30

10. Scale Compositions . . . . . . . . . . . . 36

11. Carbon Dioxide Content of Scale . . . . . . . . . . 37

12. Weight Concentration of Scale Components . . . . . . . . 37

13. Salt Free Components as Oxides . . . . . . . . . . . 37

14. Estimated Scale Composition . . . . . . . . . . . 39

15. Stagnant Seawater Nucleation Test Condition . . . . . . . 49

16. Initial Test Gulf Stream Seawater Chemistry . . . . . . . 52

17. Seawater $\mathrm{pH}$ and Alkalinity after 30-Day Exposure . . . . . 53

18. Final Dissolved Metal Concentrations . . . . . . . . . . 54

19. Total Surface Concentrations . . . . . . . . . . . 58

20. Sea Salt Corrected Calcium and Magnesium Data . . . . . . 64 
INVESTIGATION OF THE CHEMISTRY OF

CALCIUM CARBONATE SCALE NUCLEATION AND GROWTH

FROM SEAWATER ON OTEC HEAT EXCHANGERS

John W. Morse, Garrett W. Brass, Lynn M. Walter, and Reed Van Valin

Rosenstiel School of Marine and Atmospheric Science University of Miami

4600 Rickenbacker Causeway

Miami, FL 33149

EXECUTIVE SUMMARY

The successful operation of an Ocean Thermal Energy Conversion (OTEC) plant is strongly dependent on the efficiency of heat exchange between seawater and a working fluid, such as liquid ammonia. Leading current plans for OTEC plants rely on heat exchanger tubes to be used to accomplish the exchange of heat between seawater and the working fluid. The heat exchanger tube walls will constitute a barrier between the two fluids with a known thermal resistance to thermal energy transfer. Deposits derived from corrosion products, precipitation of dissolved seawater components and biofouling may form on the heat exchanger tube surfaces. These deposits can significantly contribute to thermal resistance between seawater and the working fluid. The rate of formation, character and resistance to cleaning procedures of these deposits is consequently of concern in OTEC plant design, and selection of heat exchanger tube materials and cleaning methods.

In order to gain a better understanding of the potential for inorganic scale deposition on OTEC heat exchanger tubes, we have conducted a series of tests using different candidate heat exchanger tube materials. The heat exchanger tube materials studied were aluminum (5052), copper-nickel $(90 / 10)$, stainless steel (AL6X), and titanium (grade 2). Tests were conducted using flowing and stagnant (unplanned) seawater as part of the Second Gulf of Mexico Biofouling and Corrosion Experiment. The deposition of inorganic solids from flowing seawater into which liquid ammonia was leaking through a hole in the test tubing samples was studled. Tests were also conducted to determine the growth rate of calcite and aragonite powders in seawater under a variety of conditions. The results of these tesț give an indication of the possible thickening rate of carbonate scale deposits on OTEC heat exchanger tube surfaces. 
Only very minor inorganic deposits were found on the surfaces of the stainless steel and titanium tubes, in both the flowing and stagnant seawater tests. Both the aluminum and copper-nickel tube surfaces accumulated significant inorganic deposits, under the flowing and stagnant seawater test conditions. The formation of the corrosion scale on the aluminum tubes, under both flowing and stagnant seawater conditions, was initially rapid, with approximately $70 \%$ of the scale found after a month or more of exposure being formed during the first day or less of exposure. Similar data on the early stages of scale formation on the copper-nickel tubes was not collected.

When Liquid ammonia was allowed to leak into seawater, flowing through test sections of tubes, through a 0.024 inch hole, thick gel-like deposits rapidly formed on the surfaces of the tubes. These deposits were primarily composed of a mixture of hydrated magnesium hydroxides and carbonates and could be easily removed by wiping.

Calcium carbonate formation was not revealed in any of these tests by $X$-ray diffraction analysis. Based on calcium concentrations, in excess of those which could be accounted for by sea salt, calcium carbonate was always only a very minor scale component. Tests conducted on calcium carbonate powders (calcite and aragonite) to determine the growth rate of calcium carbonate from seawater under a variety of conditions, indicated that even If tube surfaces are entirely coated with calcium carbonate the rate of scale growth will probably be less than $20 \mu \mathrm{m}$ per month under conditions that can reasonably be expected to be found in OTEC heat exchanger tubes. 


\section{INVESTIGÁTION OF THE CHEMISTRY OF CALCIUM CARBONATE SCALE NUCLEATION AND GROWTH FROM SEAWATER ON OTEC HEAT EXCHANGERS}

John W. Morse, Garrett W. Brass, Lynn M. Walter, and Reed Van Valin

\section{Rosenstiel School of Marine and Atmospheric Science University of Miami 4600 Rickenbacker Causeway Miami, FL 33149 \\ ABSTRACT}

The potential for calcium carbonate scale formation, from supersaturated seawater on candidate Ocean Thermal Energy Conversion heat exchanger tubes, has been tested under flowing and stagnant seawater, and leaking liquid ammonia conditions. It was not possible to confirm the existence of calcium carbonate in any of the deposits formed. However, the presence of calcium in the deposits, generally as a minor component, indicates that microcrystalline calcium carbonate may be formed. Tests performed on growth rates of calcite and aragonite powders in seawater indicate that the maximum thickening rate of a calcium carbonate scale, under conditions which are likely to be encountered in heat exchanger tubes, is less than $20 \mu \mathrm{m}$ per month.

\section{INTRODUCTION}

The potential for calcium carbonate scale deposition on Ocean Thermal Energy Conversion (OTEC) heat exchangers was examined in detail in the report "A Literature Review of the Saturation State of Seawater with Respect to Calcium Carbonate and Its Possible Significance for Scale Formation on OTEC Heat Exchangers" by Morse, de Kanel and Craig (1978). In that report, data were presented which indicated that, with the possible exception of Pacific Ocean deep water, all seawater coming in contact with OTEC heat exchangers is likely to be significantly supersaturated with respect to calcium carbonate. It was concluded that, if calcium carbonate nucleation occurs, there is a high probability of calcium carbonate scale growth on OTEC heat exchangers which could severly lower the operating efficlency of an OTEC plant.

In order to more clearly establish the likelihood of calclum carbonate scale formation on potential OTEC heat exchanger materials, several different 
types of tests were conducted. As part of the second Gulf of Mexico biofouling and corrosion experiment (GOME II), the inorganic chemical composition of deposits formed on candidate OTEC heat exchanger materials, after various periods of exposure to flowing seawater, was determined. Laboratory tests have also been conducted to determine if calcium carbonate is nucleated on candidate OTEC heat exchanger materials when liquid ammonia leaks into flowing seawater and when candidate heat exchanger tubes are exposed to stagnant seawater. The deposition rate of calcium carbonate on calcite and aragonite powders exposed to seawater at various saturation states with respect to these calcium carbonate phases was also determined in order to establish the relationship between scale growth rates and seawater chemistry. The test procedures and results are presented in the following sections of this report.

\section{GOME II INORGANIC SCALE CHEMISTRY}

\section{A. Summary}

The problems encountered in GOME II, with variable seawater flow rates and stagnation of the seawater in the test pipes, along with the 1ack of frequent sampling, make it difficult to draw substantial conclusions about the buildup and chemistry of the non-biogenic deposits. The results indicate that aluminum and copper-nickel pipes accumulate similar total amounts of inorganic material on their surfaces during equivalent exposure periods to flowing seawater. 'l'itanium and Aḯx stalnless stee1 plpe surfaces accumilate less than $10 \%$ as much inorganic material as the aluminum and copper-nicke1 pipe surfaces. During stagnation virtually all inorganic deposits are lost. The formation of inorganic deposits on the aluminum pipe surfaces is initially very rapid, with approximately $70 \%$ of the material found after 48 days exposure being deposited during the first 15 minutes. The copper-nickel pipes may behave in the same manner.

Al1 test pipes, except the aluminum pipes, exhibited a strong enrichment with respect to calcium over magnesium. This may be indicative of calcium carbonate formation. The aluminum pipes had an initial enrichment of magnesium over calcium, but on extended exposure averaged close to seawater.

The results indicate that a more careful set of tests should be conducted to determine the influence of initial surface characteristics on the formation of inorganic deposits on aluminum and copper-nickel pipe surfaces. The possibility of removing inorganic deposits by letting seawater stagnate 
in the heat exchangers should be investigated.

\section{B. Introduction}

The formation of biologic or chemical deposits on heat 'exchanger surfaces in an Ocean Thermal Energy Conversion (OTEC) plant is of concern because such deposits may severly retard heat transfer between seawater and the working fluid. The formation of deposits on heat exchanger surfaces is a certainty. What is not known is how fast such deposits will form, what their composition will be and how difficult they will be to remove. In order to gain preliminary data on the rate of formation and character of deposits, which may form on OTEC heat exchangers in an operating OTEC plant, tests were made using candidate OTEC heat exchanger materials. In these tests seawater was pumped through pipes of the candidate materials at a velocity approximating that which is expected in an operating OTEC plant $(6 \mathrm{ft} / \mathrm{sec})$. The resistance to heat transfer was monitored throughout the tests using the CarnegieMellon $R_{f}$ device and samples of the pipes were taken at various times to determine the type and thickness of deposits formed. The results of these tests should allow a relationship to be established between the increase in resistance to heat transfer and the evolution of the deposits on the test pipes.

The deposts were characterized in several ways. These include microscopic examination with primary emphasis on biological colonization, measurement of the wet thickness of the deposit, and determination of the surface concentration of major inorganic components. The present report is restricted to the inorganic chemistry of the deposits encountered during the second Gulf of Mexico biofouling and corrosion experiment.

\section{Pipe Surface Chemistry Analytic Procedure}

The procedure used for the determination of concentration of inorganic scale components on OTEC heat exchanger test pipes was that recommended by Morse and Craig (1978). A one inch pipe sample was given a.quick rinse in double distilled water to remove excess sea salt. It was then immersed in a $3 \%$ acetic acid solution for 24 hours. The initial volume of the acid solution was $40 \mathrm{ml}$. The pipe sample was removed and a rinse of the pipe was added to the acid solution. The solution was then transferred to a $50 \mathrm{ml}$ 
volumetric flask and the beaker rinsed into the volumetric flask until a volume of $50 \mathrm{ml}$ was obtained. Selected metal concentrations in the solution were then determined by graphite furnace and flame atomic absorption spectroscopy (Segar and Cantillo, 1975). The geometric surface area of the pipe was calculated and the metal concentration in nmoles per $\mathrm{cm}^{2}$ of surface area determined.

Two corrections have been applied to the calculated surface concentrations. The first was a blank correction based on pipe samples which were cleaned, but not exposed to seawater. The concentration of the selected metals on the control pipe were subtracted from those on the lest pipes. The second correction was applied to major sea salt components. Morse and Craig (1978) found that chloride and sodium are present on the pipe surfaces in ratios close to that tound in sea salc. They lateipleted thio oboorvation as the sodium and chloride being representative of the amount of sea salt left on the surface during drying procedures. At present it is not possible to determine what fraction of the seawater, from which the salt is derived, is present in a porous surface scale and what portion is merely seawater that was left on the scale surface in spite of rinsing with distilled water. Using seawater concentration ratios, the sea salt component of calcium and magnesium was subtracted from thels suiface concentratione to yield "excess" calcium and magnesium surface concentrations. These "excess" concentrations are às̄imed to represtul cảlium and magnocium concentrations in the solid scale.

D. Results

Pertinent background information on the samples providcd for analysis is summarized in Table 1. It is important to note the difficulties encountered in pumping seawater through the test pipes.

The mcasured absolute surface nnncentrations are presented in Table 2 . The blank corrected surface concentrations are presented in Table 3 . In Table 4, the magnesium and calcium concentrations, in excess of the maximum contribution from sea salt, are presented. These values were calculated assuming either all the sodium or potassium were representative of sea salt. 
Table 1

SAMPLE INFORMATION

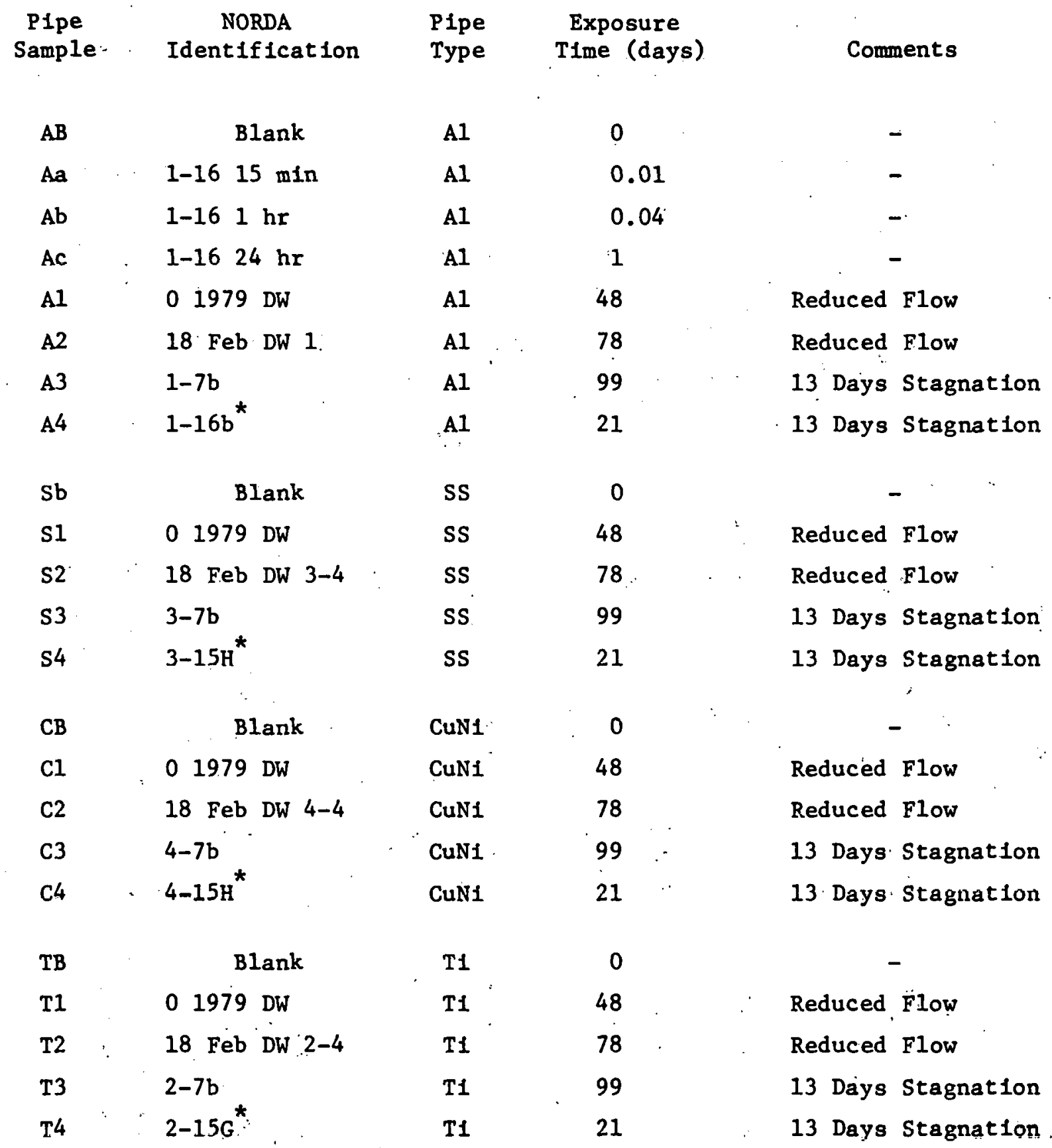

Replacement pipes put into the system after 78 days operation 
Table 2

Abso-ute Surface Concentrations

\begin{tabular}{|c|c|c|c|c|c|c|c|c|c|}
\hline Sample & $\mathrm{Na}$ & $\mathrm{K}$ & $\mathrm{Ca}$ & $\mathrm{Mg}$ & $\mathrm{Fe}$ & $\mathrm{Cr}$ & $\mathrm{N} 1$ & $\mathrm{Cr}$ & Al \\
\hline$A B$ & 0.174 & 0.014 & $0.033^{\circ}$ & 0.688 & 0.257 & $0 .(11) 07$ & - & - & 4.12 \\
\hline $\begin{array}{l}\mathrm{Aa} \\
\mathrm{Ab}\end{array}$ & $\begin{array}{r}232 \\
51.5\end{array}$ & $\begin{array}{l}9.8 \\
6.1\end{array}$ & $\begin{array}{l}18.5 \\
34.3\end{array}$ & $\begin{array}{l}913 \\
670\end{array}$ & $\begin{array}{l}71.6 \\
194\end{array}$ & $\begin{array}{l}2.59 \\
0.020\end{array}$ & - & - & $\begin{array}{l}5820 \\
5020\end{array}$ \\
\hline $\begin{array}{l}\text { Ac } \\
\text { Al }\end{array}$ & $\begin{array}{l}83.7 \\
103\end{array}$ & $\begin{array}{l}8.7 \\
2.11\end{array}$ & $\begin{array}{l}39.1 \\
211\end{array}$ & $\begin{array}{l}560 \\
816\end{array}$ & $\begin{array}{l}138 \\
199\end{array}$ & $\begin{array}{l}1.55 \\
0.70\end{array}$ & - & - & $\begin{array}{l}5490 \\
8120\end{array}$ \\
\hline A2. & 71.8 & 1.47 & 202 & 1240 & 292 & $49 . \epsilon$ & - & - & 13500 \\
\hline $\begin{array}{l}\text { A3 } \\
\text { A4 }\end{array}$ & $\begin{array}{l}0.418 \\
1.26\end{array}$ & $\begin{array}{l}0.006 \\
0.015\end{array}$ & $\begin{array}{l}0.355 \\
0.247\end{array}$ & $\begin{array}{l}\overline{1} .94 \\
\overline{1} .50\end{array}$ & $\begin{array}{l}0.191 \\
0.321\end{array}$ & $\begin{array}{l}0 . \operatorname{CD9} \\
0 . \operatorname{CD10}\end{array}$ & - & - & $\begin{array}{l}12.0 \\
14.3\end{array}$ \\
\hline SB & 0.232 & 0.016 & 0.019 & 0.010 & 1.22 & $0 . C 172$ & 0.0494 & 0.0655 & - \\
\hline S1 & 105 & 1.96 & 34.3 & 60.9 & 392 & 54.5 & 2.62 & 48.2 & - \\
\hline S2 & 225 & 4.63 & $\div 6.2$ & 54.8 & 178 & 16.5 & 12.5 & 13.8 & - \\
\hline s3 & 0.418 & 0.0061 & 0.148 & 0.087 & 0.490 & 1.12 & 0.207 & 0.0435 & - \\
\hline 54 & 0.760 & 0.0121 & 0.074 & 0.061 & 0.178 & 0.233 & 0.0529 & 0.0134 & - \\
\hline $\mathrm{CB}$ & 0.277 & 0.0242 & 0.022 & $<0.006$ & 0.064 & 2.59 & 0.373 & - & - \\
\hline $\mathrm{Cl}$ & 322 & 7.13 & 191 & 365 & 3680 & 9160 & 2370 & - & - \\
\hline C2 & 96.6 : & 2.15 & $1 \dot{4} 1$ & 23i & 3600 & 8810 & 2070 & - & - \\
\hline C3 & 0.843 & 0.0159 & 0.484 & 0.548 & 5.62 & 11.1 & 2.90 & - & - \\
\hline $\mathrm{C4}$ & 3.28 & 0.0462 & 0.133 & 0.317 & 0.981 & 6.85 & 1.13 & - & - \\
\hline TB & 0.084 & 0.0061 & 0.02 & 0.006 & 1.46 & $0 . C 745$ & - & - & - \\
\hline T1 & 83.7 & 1.79 & 12.2 & 36.5 & 119 & 44 & - & - & - \\
\hline $\mathrm{T} 2$ & 70.8 & 1.56 & 18.5 & 38.2 & 84.8 & 7.7 & - & - & - \\
\hline T3 & 0.393 & 0.0062 & 0.041 & 0.049 & 0.284 & 0.1 .33 & - & - & - \\
\hline T4 & 2.63 & 0.0242 & 0.067 & 0.146 & 0.066 & $0 . C 326$ & - & - & - \\
\hline
\end{tabular}

All concentrations in nmoles. $\mathrm{cm}^{2}$; All 21 valces $<0.003 ; \mathrm{AB}, \mathrm{SB}, \mathrm{CB}$ and $\mathrm{TB}$ are blank values dertved from pipes not exposed to seawater. 
Table 3

Blank Corrected Surface Concentrations

\begin{tabular}{|c|c|c|c|c|c|c|c|c|c|}
\hline Sample & $\mathrm{Na}$ & K & $\mathrm{Ca}$ & $\mathrm{Mg}$ & $\mathrm{Fe}$ & $\mathrm{Cu}$ & $\mathrm{NI}$ & $\mathrm{Cr}$ & Al \\
\hline $\mathrm{Aa}$ & 232 & 9.8 & 18.5 & 913 & 71.3 & 2.59 & & & 5820 \\
\hline $\mathrm{Ab}$ & 51.3 & 6.1 & 34.3 & 670 & 194 & .0 .019 & - & - & 5020 \\
\hline Ac & 83.5 & 8.7 & 39.1 & 560 & 138 & 1.56 & - & - & 5490 \\
\hline A1 & 103 & 2.10 & 211 & 816 & 199 & 0.70 & - & - & 8120 \\
\hline $\mathrm{A} 2$ & 71.6 & 1.36 & 202 & 1240 & 292 & 49.6 & - & - & 13500 \\
\hline A3 & 0.244 & -0.008 & 0.322 & 1.25 & -0.066 & 0.002 & - & - & -7.9 \\
\hline A4 & 1.05 & 0.001 & 0.214 & 0.81 & 0.064 & 0.0003 & - & - & 10.2 \\
\hline s1 & 105 & 1.95 & 34.3 & 60.9 & 391 & 34.5 & 2.57 & 48.1 & - \\
\hline S2 & 225 & 4.62 & 46.2 & 54.8 & $177^{\circ}$ & 16.5 & 12.5 & 13.7 & - \\
\hline s3 & 0.186 & -0.010 & 0.129 & 0.077 & -0.23 & 1.10 & 0.158 & -0.0222 & - \\
\hline 54 & 0.528 & -0.040 & 0.055 & 0.051 & -1.04 & 0.216 & 0.0035 & -0.0521 & - \\
\hline $\mathrm{Cl}$ & 322 & 7.12 & 191 & 365 & 3680 & 9180 & 2370 & - & - \\
\hline $\mathrm{C} 2$ & 96.3 & $\quad 2.13$ & 141 & 237 & 3600 & 8810 & 2070 & -. & - \\
\hline C3 & 0.566 & -0.0083 & 0.462 & 0.548 & 5.56 & 8.5 & 2.53 & - & - \\
\hline $\mathrm{C4}$ & 3.00 & 0.0220 & 0.111 & 0.317 & 0.917 & 4.26 & 0.76 & - &.- \\
\hline $\mathrm{T} 1$ & 83.6 & 1.78 & 12.2 & 36.5 & 118 & 44 & - & - & - \\
\hline $\mathrm{T} 2$ & 70.7 & 1.55 & 18.5 & 38.2 & 83.3 & 7.6 & - & _- & _ \\
\hline $\mathrm{T} 3$ & 0.309 & 0.0001 & 0.041 & 0.049 & -1.18 & 0.058 & - & - &.- \\
\hline $\mathrm{T} 4$ & 2.55 & 0.0181 & 0.067 & 0.146 & -1.39 & -0.0419 & - & - & $-\ddot{-}$ \\
\hline
\end{tabular}

All concentrations in nmoles $/ \mathrm{cm}^{2}$ All $\mathrm{T} 1$ values $<0.003$ 
Table 4

CALCIUM AND MAGNESIUM RELATIONS

\begin{tabular}{|c|c|c|c|c|c|c|c|c|c|}
\hline $\begin{array}{l}\text { Pipe } \\
\text { Sample }\end{array}$ & $\mathrm{C}_{\mathrm{Mg}}^{*}$ & $\mathrm{C}_{\mathrm{Ca}}^{\star}$ & $\frac{\mathrm{C}_{\mathrm{Mg}}^{*}}{\mathrm{C}_{\mathrm{Ca}}^{\star}}$ & $R^{\star}$ & $\mathrm{C}_{\mathrm{Mg}}^{\star \star *}$ & $\mathrm{C}_{\text {Ca }}^{\text {*a }}$ & $\frac{\mathrm{C}_{\mathrm{Mg}}^{\star *}}{\frac{\mathrm{C}_{\mathrm{Ca}}^{\star *}}{\mathrm{Cat}^{*}}}$ & $R^{\star \star}$ & $\frac{\mathrm{C}_{\mathrm{Mg}}^{*}}{\mathrm{C}_{\mathrm{Mg}}^{\star *}}$ \\
\hline $\begin{array}{l}\mathrm{Aa} \\
\mathrm{Ab} \\
\mathrm{Ac} \\
\mathrm{A} 1 \\
\mathrm{~A} 2 \\
\mathrm{~A} 3 \\
\mathrm{~A} 4\end{array}$ & $\begin{array}{r}886 \\
664 \\
550 \\
804 \\
1231 \\
1.22 \\
0.69\end{array}$ & $\begin{array}{l}13.4 \\
33.2 \\
37.3 \\
209 \\
200 \\
\because 0.32 \\
0.19\end{array}$ & $\begin{array}{c}66.1 \\
20.0 \\
14.8 \\
3.85 \\
6.15 \\
3.86 \\
3.62\end{array}$ & $\begin{array}{l}12.7 \\
3.70 \\
2.37 \\
0.75 \\
1.20 \\
0.75 \\
0.70\end{array}$ & $\begin{array}{r}862 \\
638 \\
514 \\
805 \\
1232 \\
1.29 \\
0.80\end{array}$ & $\begin{array}{c}8.63 \\
28.2 \\
30.3 \\
208 \\
201 \\
0.33 \\
0.21\end{array}$ & $\begin{array}{l}99.9 \\
22.7 \\
17.0 \\
3.85 \\
6.15 \\
3.91 \\
3.77\end{array}$ & $\begin{array}{r}19.44 \\
4.41 \\
3.30 \\
0.75 \\
1.19 \\
0.76 \\
0.73\end{array}$ & $\begin{array}{l}1.00 \\
1.04 \\
1.07 \\
1.00 \\
1.00 \\
0.95 \\
0.99\end{array}$ \\
\hline $\begin{array}{l}\text { S1 } \\
\text { s2 } \\
\text { s3 } \\
\text { s4 }\end{array}$ & $\begin{array}{c}49.1 \\
29.5 \\
0.06 \\
-0.01\end{array}$ & $\begin{array}{c}32.0 \\
41.3 \\
0.12 \\
0.04\end{array}$ & $\begin{array}{r}1.53 \\
0.71 \\
0.44 \\
-0.19\end{array}$ & $\begin{array}{r}0.30 \\
0.14 \\
0.199 \\
-0.14\end{array}$ & $\begin{array}{c}50.8 \\
30.9 \\
0.13 \\
0.26\end{array}$ & $\begin{array}{r}32.3 \\
41.5 \\
0.14 \\
0.10\end{array}$ & $\begin{array}{l}1.57 \\
0.74 \\
0.92 \\
2.7\end{array}$ & $\begin{array}{l}0.31 \\
0.14 \\
0.18 \\
0.53\end{array}$ & $\begin{array}{r}0.97 \\
0.95 \\
0.46 \\
-0.04\end{array}$ \\
\hline $\begin{array}{l}\text { C1 } \\
\text { C2 } \\
\text { C3 } \\
\text { C4 }\end{array}$ & $\begin{array}{l}329 \\
226 \\
\quad 0.48 \\
-0.02\end{array}$ & $\begin{array}{l}184 \\
139 \\
0.45 \\
0.05\end{array}$ & $\begin{array}{r}1.79 \\
1.63 \\
1.08 \\
-0.46\end{array}$ & $\begin{array}{r}0.35 \\
0.32 \\
0.21 \\
-0.09\end{array}$ & $\begin{array}{r}328 \\
226 \\
0.59 \\
0.20\end{array}$ & $\begin{array}{r}184 \\
139 \\
0.47 \\
0.08\end{array}$ & $\begin{array}{l}1.79 \\
1.63 \\
1.26 \\
2.29\end{array}$ & $\begin{array}{l}0.35 \\
0.32 \\
0.24 \\
0.45\end{array}$ & $\begin{array}{r}1.00 \\
1.00 \\
0.81 \\
-0.10\end{array}$ \\
\hline $\begin{array}{l}\text { T1 } \\
\text { T2 } \\
\text { T3 } \\
\text { T4 }\end{array}$ & $\begin{array}{c}27.1 \\
30.2 \\
0.01 \\
-0.14\end{array}$ & $\begin{array}{c}10.4 \\
17.0 \\
0.03 \\
0.01\end{array}$ & $\begin{array}{r}2.61 \\
1.78 \\
0.42 \\
-12.7\end{array}$ & $\begin{array}{r}0.51 \\
0.35 \\
0.08 \\
-2.47\end{array}$ & $\begin{array}{c}27.3 \\
30.2 \\
0.05 \\
0.05\end{array}$ & $\begin{array}{c}10.4 \\
16.9 \\
0.04 \\
0.05\end{array}$ & $\begin{array}{l}2.62 \\
1.78 \\
1.19 \\
1.07\end{array}$ & $\begin{array}{l}0.51 \\
0.34 \\
0.23 \\
0.21\end{array}$ & $\begin{array}{c}0.99 \\
0.10 \\
0.20 \\
-2.8\end{array}$ \\
\hline
\end{tabular}

* Corrected for sea salt Lsing Na

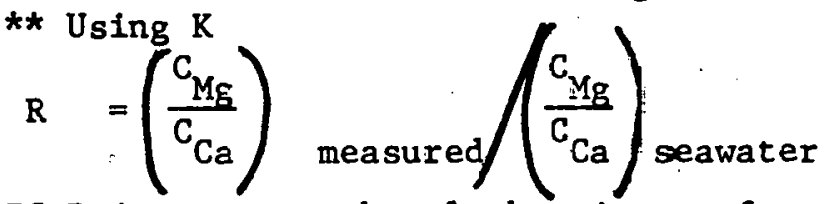

If $R$ is greater than $I$ the pipe surface is enriched with $M g$; if $R$ is less than 1 the pipe surface is enriched in $\mathrm{Ca} .2$

$C$ is in nmoles $/ \mathrm{cm}^{2}$. 


\section{E. Discussion}

There are major problems in interpreting the results of GOME II. The first is the variation of flow rates and exposure of the samples to stagnant water for extended periods of time. This problem also plagued GOME I. The second problem is that, with the exception of the three short term aluminum pipe samples which were collected at my request, only three exposure times are available. The sample from the third exposure time was collected after the samples had been exposed to stagnant seawater for 10 days. Consequently, it is impossible to draw any conclusions about the evolution of the inorganic deposits. The third problem is the lack of sample replicates. This makes it impossible to assess the significance of observed differences. In light of these problems, the following interpretation of the results should be taken as highly tentative.

The total concentration of inorganic components is similar for the aluminum and CuNi pipes. Both the stainless steel and titanium pipes had only very minor surface deposits, which were less than $10 \%$ of those found on the aluminum and CuNi pipes for exposure times of 48 and 78 days. On the aluminum pipes, approximately $70 \%$ of Al scale component found at 48 days is present after only 15 minutes. This observation supports the contention of $\mathrm{Dr}$. Manfred Kaminsky and myself, as expressed at the Biofouling and Corrosion Workshop, that the initial state of the surface is important in determining the rate and pathway of scale formation. It is recommended that further tests be conducted on this problem.

The high $\mathrm{Fe}$ concentrations of the CuNi pipe samples from 48 and 78 days exposure are surprising. This observation has been confirmed by Ms. Brenda Little (conversation May 5, 1979) through EDAX analysis. The source and accumulation mechanism for the Fe should be investigated.

All the samples which were exposed to the stagnant seawater between the 78 and 99 day periods lost virtually all of their inorganic deposits. If the biofouling deposits didn't rapidly increase during this period, then exposure of heat exchangers to stagnant conditions may be a way of removing surface deposits. This should be studied in detail.

All test pipes, except the aluminum pipes, exhibited a strong enrichment with respect to $\mathrm{Ca}$ over $\mathrm{Mg}$. This may be indicative of $\mathrm{CaCO}_{3}$ formation. The aluminum pipes had an initial enrichment with $\mathrm{Mg}$ over $\mathrm{Ca}$ but on extended 
exposure averaged close to seawater.

\section{CALCITE AND ARAGONITE POWDER GROWTH RATE TESTS}

\section{A. Summary}

The growth rates of synthetic calcite and aragonite powders, at 25 and $7^{\circ} \mathrm{C}$ and at various saturation states, were determined in natural seawater containing different concentrations of silica, phosphate and nitrate. At a given temperature, calcite and aragonite growth rates are similar at the same degree of supersaturation. However, at typical surface seawater supersaturation values, calcite should precipitate faster than aragonite since the seawacer is more supersaturated with respect to calcite than aragonite. Growth rate constants for both calcite and aragonite are an order of magnitude less at $7^{\circ} \mathrm{C}$ than $25^{\circ} \mathrm{C}$. At typical surface seawater supersaturations the scale thickening rates calculated from these tests for calcite and aragonite are, respectively $18.2 \mu \mathrm{m} /$ and $10.2 \mu \mathrm{m} / \mathrm{month}$ assuming they form as nonporous solids and that they are not exposed to significant inhibitors derived from corrosion or biofouling products.

Nitrate had no measurable effect on calcite or aragonite growth rates. Silica has a slight inhibiting effect on calcite growth in seawater that is 5 times supersaturated. It has a very strong effect on aragonite precipitation at 3 times supersaturation, At dissolved silica concentrations of only 50 umoles per liter, the growth rate of aragonite is half that found in silica-free seawater. Phosphate, at a concentration of only $10 \mu$ moles per liter, slows both calcite and aragonite growth rates.

\section{B. Introduction}

If calclum carbonate nucleates on OTEC heat exchangers, a significant deterioration in the thermal efficiency of heat transport may result if this calcium carbonate scale thickens as a result of growth of the calcium carbonate from the supersaturated seawater passing through the heat exchangers. Little is presently known about the dependence of calcite and aragonite growth kinetics on the degree of seawater supersaturation, temperature and concentration of possible inhibitors whose concentration in seawater varies significantly. In order to obtain information on these parameters, we have conducted a series of tests using synthetic calcite and 
aragonite powders. The results of these tests and their significance to probable OTEC heat exchanger behavior are the basis of this report.

\section{Test Procedures}

Calcite and aragonite are the two most probable calcium carbonate phases which may be nucleated on the surfaces of OTEC heat exchangers. Consequently, synthetic powders of these two calcium carbonate phases were chosen for testing calcium carbonate growth rates from seawater. The synthetic calcite used in these tests was Mallinckrodt brand reagent grade calcium carbonate. It was size separated by differential settling in double distilled water. The 1 to $20 \mu \mathrm{m}$ size was used for these tests. The synthetic aragonite used in these tests was synthesized by the method of Wray and Daniels (1957), as modified by Katz (1972). The surface areas of the calcite and aragonite, as determined by the $\mathrm{Kr}-\mathrm{BET}$ method of de Kanel and Morse (1979), were respectively 0.40 and $1.4 \mathrm{~m}^{2} \mathrm{~g}^{-1}$.

The seawater, which was used in these tests, was freshly collected Gulf Stream surface seawater. Its saturation state was altered either by acid (HC1) addition or through dissolution of calcium carbonate at a higher partial pressure of $\mathrm{CO}_{2}$ than that used in the growth tests. The concentration of nutrients in the seawater was less than 1 micromolal for silica, nitrate and phosphate, as determined by the methods of Strickland and Parsons (1972). In order to determine the effects of these nutrients on growth rates, reagent grade salts, of these nutrients were dissolved in disdistilled water and added to the seawater to produce the desired concentration levels. Stated temperatures were maintained during the experiments by circulating water through the reaction vessel's outer jacket from a temperature controlled water bath.

Growth rates were determined at constant degrees of supersaturation using the pH-stat method of Morse (1974), as modified for growth rate studies by Berner (1975). All tests were made at a $\mathrm{CO}_{2}$ partial pressure of $10^{-2.52}$ atmospheres using a $\mathrm{CO}_{2}-\mathrm{N}_{2}$ gas mixture.

Saturation states were calculated under the experimental conditions using the method presented by Millero and Morse (1979). This method is based on the $\mathrm{CO}_{2}$ solubility in seawater of Weiss (1974), the carbonic acid system apparent constants in seawater of Mehrbach et al. (1973), the boric acid apparent dissociation constant in seawater of Lyman (1957) and the 
apparent solubility constants for calcite and aragonite in seawater of Morse et al. (1979) fit to the temperature and salinity dependence of Ingle (1975). D. Results

The results of the calcium carbonate powder growth rate tests are presented in Table 5. Calcium carbonate dissolution rates have been found (e.g. Morse, 1978) to follow the classical equation relating reaction rate to distance from equilibrium

$$
\mathbf{R}=\mathbf{k}(\Omega-1)^{\mathbf{n}}
$$

where $R$ is the reaction rate, $k$ is the rate constant, $\Omega$ is the saturation state expressed as the ratio of total ion molal product (IMP) of $\mathrm{Ca}^{2+}$ and $\mathrm{CO}_{2}{ }^{2-}$ to the apparent solubility constant of calcite $\left(\mathrm{K}_{\mathrm{c}}{ }^{\prime}\right.$ ) or aragonite $\left(\mathrm{K}_{\mathrm{a}}{ }^{\prime}\right)$ and $\mathrm{n}$ is the order of the reaction. In logarithmic form this equation is

$$
\log \mathrm{R}=\log \mathrm{K}+\mathrm{n} \log (\Omega-1)
$$

Thus, if the $\log$ of the reaction rate is plotted against the $\log$ of $(\Omega-1)$ and a straight line is obtained the reaction follows this rate law. The rate constant and order of the reaction can be determined by the intercept and slope of the line. The results obtained for tests conducted in the low nutrient seawater have been plotted in this manner in Figure 1. The values of $k$ and $n$ were calculated by the least squares method. Results of these calculations and the correlation coefficient of the data with the straight line model are presented in, l'able 6 . With the possible exception of the low. temperature aragonite results, the data have an excellent correlation with this model and the rate constants at $7^{\circ} \mathrm{C}$ are approximately an order magnitude less than at $25^{\circ} \mathrm{C}$ for both calcite and aragonite.

The ratio of the reaction rate obtained in seawater, to which nutrients $\left(\mathrm{NO}_{3}, \mathrm{PO}_{4}\right.$ or $\left.\mathrm{SiO}_{3}\right)$ were added, to the reaction rate obtained at the same saturation state in seawater containing less than $1 \mu \mathrm{M} \ell^{-1}$ of these nutrients, are presented in Table 7. There was no measurable effect of nftrate on reaction rate. At $25^{\circ} \mathrm{C}$ and supersaturations typical of near surface seawater, phosphate at a concentration of $10 \mu \mathrm{M}$ reduced the calcite growth rate by approximately $50 \%$ and reduced the aragonite growth rate by a factor of at least 100 (to a value below our detection limit). Under the same conditions silica had only a minor effect (11\%) on calcite growth rates at a silica concentration of $500 \mu \mathrm{M}$, but reduced the aragonite growth rate 
Table 5

CALCITE AND ARAGONITE POWDER GROWTH TEST DATA

\begin{tabular}{|c|c|c|c|c|c|c|c|c|c|}
\hline Solid & $\begin{array}{l}\text { Temperature } \\
\begin{array}{c}\left({ }^{\circ} \mathrm{C}\right) \\
\end{array}\end{array}$ & $\begin{array}{l}\mathrm{NO}_{3} \\
(\mu \mathrm{M}) \\
\end{array}$ & $\begin{array}{c}\mathrm{Si} \\
(\mu \mathrm{M})\end{array}$ & $\begin{array}{l}\mathrm{PO}_{4} \\
(\mu \mathrm{M}) \\
\end{array}$ & $\mathrm{pH}$ & $\underline{\Omega}$ & $\underline{\log (\Omega-1)}$ & $\begin{array}{c}\text { Rate } \\
\left(\mu \text { moles } \mathrm{cm}^{-2} \mathrm{hr}^{-1}\right)\end{array}$ & Log Rate \\
\hline Calcite & 25 & $<1$ & $<1$ & $<1$ & 7.630 & 2.90 & 0.279 & 0.0107 & -1.972 \\
\hline Calcite & 25 & $<1$ & $<1$ & $<1$ & 7.670 & 3.45 & 0.389 & 0.0207 & -1.684 \\
\hline Calcite & 25 & $<1$ & $<1$ & $<1$ & 7.720 & 4.40 & 0.532 & 0.0505 & -1.296 \\
\hline Calcite & 25 & $<1$ & $<1$ & $<1$ & 7.770 & 5.50 & 0.653 & 0.0876 & -1.058 \\
\hline Calcite & 25 & $<1$ & $<1$ & $<1$ & 7.780 & 5.75 & 0.677 & 0.0809 & -1.092 \\
\hline Calcite & 25 & $<1$ & $<1$ & $<1$ & 7.800 & 6.25 & 0.720 & 0.118 & -0.929 \\
\hline Calcite & 25 & $<1$ & $<1$ & $<1$ & 7.830 & 7.15 & 0.789 & 0.162 & -0.791 \\
\hline Calcite & 7 & $<1$ & $<1$ & $<1$ & 7.800 & 4.45 & 0.538 & 0.0067 & -2.176 \\
\hline Calcite & 7 & $<1$ & $<1$ & $<1$ & 7.825 & 5.00 & 0.602 & 0.0127 & -1.896 \\
\hline Calcite & 7 & $<1$ & $<1$ & $<1$ & 7.830 & 5.10 & 0.613 & 0.0169 & -1.773 \\
\hline Calcite & 7 & $<1$ & $<1$ & $<1$ & 7.845 & 5.50 & 0.653 & 0.0200 & -1.699 \\
\hline Calcite & 7 & $<1$ & $<1$ & $<1$ & 7.865 & 6.00 & 0.699 & 0.0243 & -1.613 \\
\hline Calcite & 7 & $<1$ & $<1$ & $<1$ & 7.865 & 6.00 & 0.699 & 0.0324 & -1.489 \\
\hline Calcite & 7 & $<1$ & $<1$ & $<1$ & 7.885 & 6.55 & 0.744 & 0.0275 & -1.561 \\
\hline Calcite & 7 & $<1$ & $<1$ & $<1$ & 7.895 & 6.85 & 0.767 & 0.0410 & -1.387 \\
\hline Calcite & 7 & $<1$ & $<1$ & $<1$ & 7.905 & 7.10 & 0.785 & 0.0342 & -1.467 \\
\hline Calcite & 7 & $<1$ & $<1$ & $<1$ & 7.905 & 7.10 & 0.785 & 0.0422 & -1.375 \\
\hline Calcite & 25 & 100 & $<1$ & $<1$ & 7.740 & 4.80 & 0.580 & 0.0685 & -1.164 \\
\hline Calctite & 25 & $<1$ & $<1$ & 10 & 7.740 & 4.80 & 0.580 & 0.0336 & -1.474 \\
\hline Calcite & 25 & $<1$ & 500 & $<1$ & 7.740 & 4.80 & 0.580 & 0.0610 & -1.215 \\
\hline
\end{tabular}


Table 5 (continued)

\begin{tabular}{|c|c|c|c|c|c|c|c|c|c|}
\hline Solid & $\begin{array}{l}\text { Temperature } \\
\left({ }^{\circ} \mathrm{C}\right) \\
\end{array}$ & $\begin{array}{l}\mathrm{NO}_{3} \\
(\mu M) \\
\end{array}$ & $\begin{array}{c}\mathrm{S1} \\
(\mu \mathrm{M}) \\
\end{array}$ & $\begin{array}{l}\mathrm{PD}_{4} \\
(\mathrm{MM}) \\
\end{array}$ & $\mathrm{pH}$ & $\underline{\Omega}$ & $\underline{\log (\Omega-1)}$ & $\begin{array}{c}\text { Rate } \\
\left(\text { mmoles } \mathrm{cm}^{-2} \mathrm{hr}^{-1}\right) \\
\end{array}$ & Log Bate \\
\hline Calcite & 7 & 100 & $<1$ & $<1$ & 7.905 & 7.10 & 0.785 & 0.0322 & -1.492 \\
\hline Calcite & 7 & $<1$ & $<1$ & 10 & 7.905 & 7.10 & 0.785 & 0.0287 & -1.543 \\
\hline Calcite & 7 & $<1$ & 500 & $=1$ & 7.905 & 7.10 & 0.785 & 0.0306 & -1.514 \\
\hline Aragonite & 25 & $<1$ & $<1$ & $=1$ & 7.670 & 2.25 & 0.097 & 0.0068 & -2.165 \\
\hline Aragonite & 25 & $<1$ & $<1$ & $\leq 1$ & 7.730 & 2.85 & 0.267 & 0.0301 & -1.522 \\
\hline Aragonite & 25 & $<1$ & $<1$ & $=1$ & 7.735 & 2.93 & 0.286 & 0.0378 & -1.422 \\
\hline Aragonite & 25 & $<1$ & $<1$ & $=1$ & 7.750 & 3.00 & 0.301 & 0.0256 & -1.591 \\
\hline Aragonite & 25 & $<1$ & $<1$ & $=1$ & 7.765 & 3.35 & 0.371 & 0.0341 & -1.467 \\
\hline Aragonite & 25 & $<1$ & $<1$ & $<1$ & 7.800 & 4.05 & 0.484 & 0.0557 & -1.254 \\
\hline Aragonite & 25 & $<1$ & $<1$ & $=1$ & 7.855 & 5.15 & 0.618 & 0.0788 & -1.104 \\
\hline Aragonite & 7 & $<1$ & $<1$ & $=1$ & 7.875 & 4.12 & 0.494 & 0.0049 & -2.310 \\
\hline Aragonite & 7 & $<1$ & $<1$ & $=1$ & 7.885 & 4.30 & 0.518 & 0.0133 & -1.876 \\
\hline Aragonite & 7 & $<1$ & $<1$ & $=1$ & 7.895 & 4.55 & 0.550 & 0.0089 & -2.051 \\
\hline Aragonite & 7 & $<1$ & $<1$ & $<1$ & 7.905 & 4.75 & 0.574 & 0.0174 & -1.759 \\
\hline Aragonite & 7 & $<1$ & $<1$ & $=1$ & 7.910 & 4.85 & 0.586 & 0.0117 & -1.932 \\
\hline Aragonite & 7 & $<1$ & $<1$ & $=1$ & 7.925 & 5.20 & 0.623 & 0.0227 & -1.644 \\
\hline Aragonite & 7 & $<1$ & $<1$ & $=1$ & 7.945 & 5.70 & 0.672 & 0.0246 & -1.609 \\
\hline Aragonite & 7 & $<1$ & $<1$ & $=1$ & 7.945 & 5.70 & 0.672 & 0.0158 & -1.801 \\
\hline Aragonite & 7 & $<1$ & $<1$ & $<1$ & 7.960 & 6.10 & 0.708 & 0.0273 & -1.564 \\
\hline Aragonite & 7 & $<1$ & $<1$ & $<1$ & 7.965 & 6.20 & 0.716 & 0.0249 & -1.604 \\
\hline Aragonite & 25 & 100 & $<1$ & $<1$ & 7.835 & 2.93 & 0.286 & 0.0311 & -1.507 \\
\hline Aragonite & 25 & $<1$ & $<1$ & 10 & 7.735 & 2.93 & 0.286 & $<0.0003$ & $<-3.5$ \\
\hline
\end{tabular}


Table 5 (continued)

\begin{tabular}{|c|c|c|c|c|c|c|c|c|c|}
\hline Solid & $\begin{array}{l}\text { Temperature } \\
\left({ }^{\circ} \mathrm{C}\right)\end{array}$ & $\begin{array}{l}\mathrm{NO}_{3} \\
(\mu \mathrm{M})\end{array}$ & $\begin{array}{l}\mathrm{S}_{1} \\
(\mu \mathrm{M})\end{array}$ & $\begin{array}{l}\mathrm{PO}_{4} \\
(\mu \mathrm{M})\end{array}$ & $\mathrm{pH}$ & $\Omega$ & $\log (\Omega-1)$ & $\left(\mu\right.$ moles $\left.\mathrm{cm}^{-2} \mathrm{hr}^{-1}\right)$ & Log Rat \\
\hline Aragonite & 25 & $<1$ & 500 & $<1$ & 7.735 & 2.93 & 0.286 & $<0.0003$ & $<-3.5$ \\
\hline Aragonite & 25 & $<1$ & 100 & $<1$ & 7.735 & 2.93 & 0.286 & 0.0093 & -2.030 \\
\hline Aragonite & 25 & $<1$ & 50 & $<1$ & 7.735 & 2.93 & 0.286 & 0.0156 & -1.808 \\
\hline Aragonite & 7 & 100 & $<1$ & $<1$ & 7.960 & 6.10 & 0.708 & 0.0283 & -1.548 \\
\hline Axagonite & 7 & $<1$ & $<1$ & 10 & 7.960 & 6.10 & 0.708 & 0.0246 & -1.609 \\
\hline fragonite & 7 & $<1$ & 500 & $<1$ & 7.960 & 6.10 & 0.708 & 0.260 & -1.584 \\
\hline
\end{tabular}

A11 runs done in Gulf Stream surface seawater at a $\mathrm{P}_{\mathrm{CO}_{2}}=10^{-2.52} \mathrm{~atm}$.

$s_{i}=\left(\mathrm{M}_{\mathrm{Ca}}+\mathrm{M}_{\mathrm{CO}_{3}}\right) /\left(\mathrm{R}_{\mathrm{c}}\right.$ or $\left.\mathrm{K}_{\mathrm{a}}\right)=$ the saturation state 
Figure 1. The $\log$ of the rate of powder growth versus the $\log$ of $(\Omega-1)$.

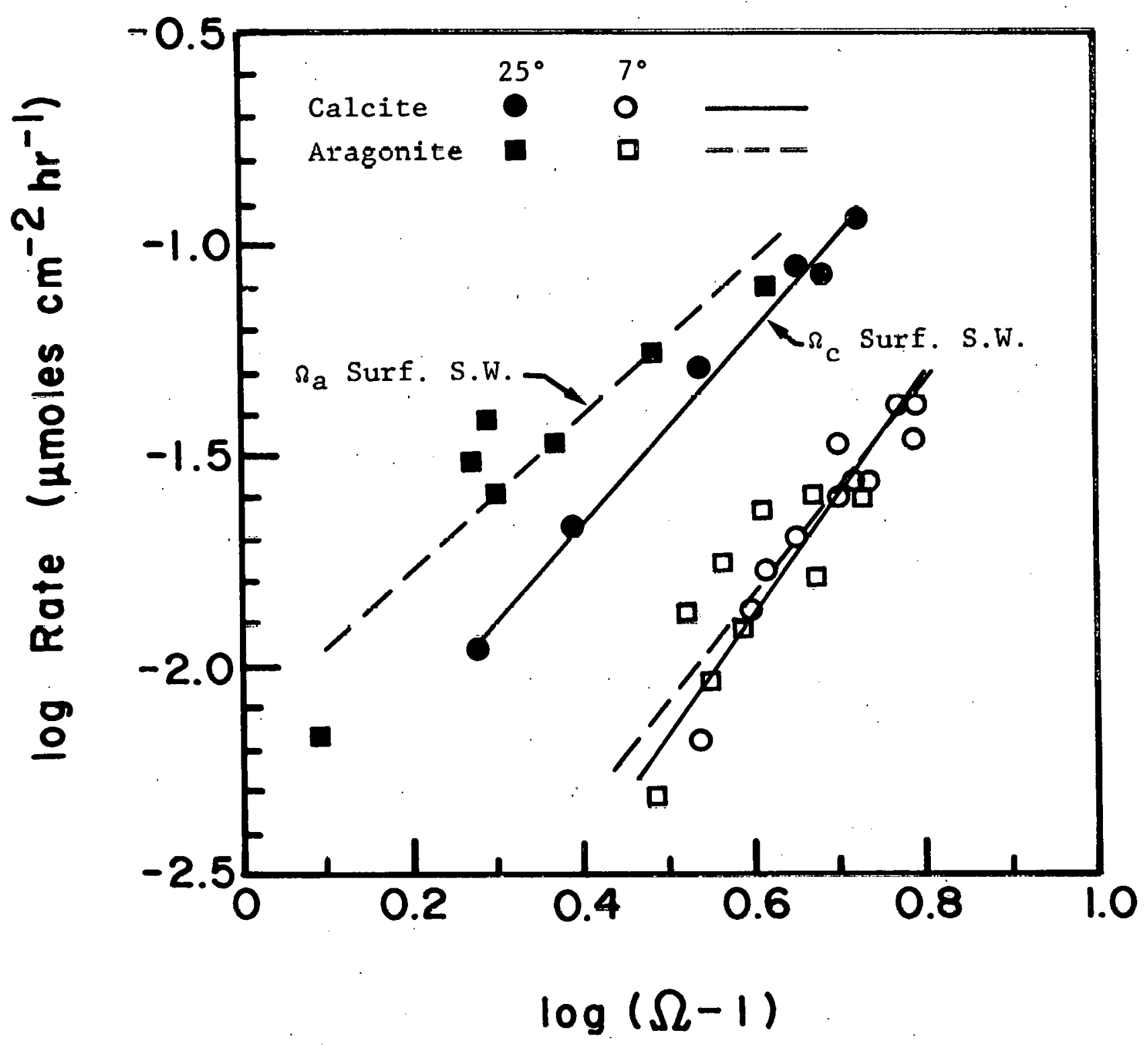


Table 6

REACTION EQUATION PARAMETERS

$\begin{array}{ccccc}\text { Solid } & \begin{array}{c}\text { Temperature } \\ \left({ }^{\circ} \mathrm{C}\right)\end{array} & \begin{array}{c}\mathrm{k} \\ \left.\text { (umoles } \mathrm{cm}^{2} \mathrm{hr}^{-1}\right)\end{array} & \mathrm{n} & \begin{array}{c}\text { Correlation } \\ \text { Coefficlent }\end{array} \\ \text { Calcite } & 25 & 2.63 \times 10^{-3} & 2.28 & 0.995 \\ \text { Calcite } & 7 & 2.63 \times 10^{-4} & 2.81 & 0.953 \\ \text { Aragonite } & 25 & 7.24 \times 10^{-3} & 1.85 & 0.919 \\ \text { Aragonite } & 7 & 4.47 \times 10^{-4} & 2.51 & 0.840\end{array}$


Table 7 .

INFLUENCE OF NUTRIENTS ON GROWTH RATE

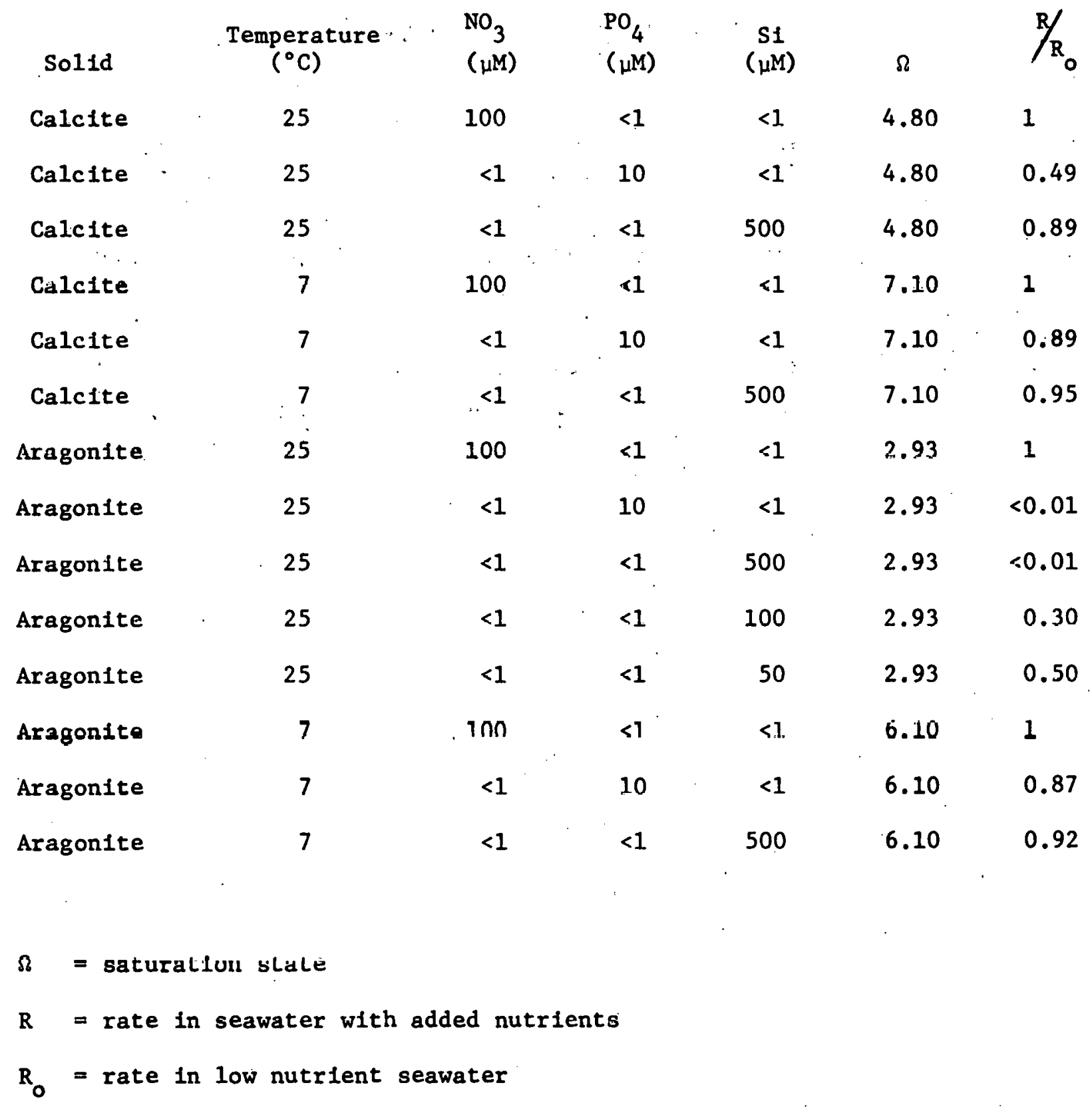


by at least a factor of 100. Silica at a concentration of $100 \mu \mathrm{M}$ reduced the aragonite growth rate by $70 \%$ and at a concentration of $50 \mu \mathrm{M}$ by $50 \%$. Because the reaction rates determined at $7^{\circ} \mathrm{C}$ were approximately an order of magnitude less than those determined at $25^{\circ} \mathrm{C}$, it was necessary to conduct the nutrient inhibition tests at higher supersaturations in order to obtain reliable results at $7^{\circ} \mathrm{C}$. Again, nitrate was found to have no measurable effect on growth rates. The growth rate of calcite was reduced $11 \%$ by phosphate at a concentration of $10 \mu \mathrm{M}$ and only $5 \%$ by silica at a concentration of $500 \mu \mathrm{M}$. The growth rate of aragonite was reduced by $13 \%$ by phosphate at a concentration of $10 \mu \mathrm{M}$ and $8 \%$ by silica at a concentration of $500 \mu \mathrm{M}$.

\section{E. Discussion}

The results of these tests indicate that both calcite and aragonite growth rates can be significantly influenced by inhibitors, such as nutrients, found in natural seawater. The relative strength of inhibition increases as the degree of supersaturation decreases. Growth rates, which may be encountered in actual OTEC heat exchangers, may be significantly lower than those measured in these tests if corrosion and biofouling contribute inhibitors either not present in seawater or raise naturally occuring inhibitor concentrations substantially above normal levels. If such inhibitors are not added, the approximate scale thickening rates for nonporous calcite and aragonite on OTEC heat exchangers exposed to typical near surface seawater are, respectively, 18.2 and $10.2 \mu \mathrm{m}$ per month.

\section{LIQUID AMMONIA INDUCED SCALE DEPOSITION}

\section{A. Summary}

The leakage of liquid ammonia into seawater, flowing through tubes of candidate OTEC heat exchanger materials, results in the rapid formation of deposits on the tube surfaces. Chemical analyses of these deposits indicates that they are dominantly composed of magnesium compounds, which are mostly magnesium hydruxides and carbonates. A minor amount of calcium carbonate may also form. The deposits are inftially highly hydrated gells, which can be easily removed by wiping. 


\section{B. Introduction}

In an OTEC plant, the heat exchangers will form a physical barrier between seawater and the working fluid, which is anticipated to be liquid ammonia. Construction faults and corrosion during plant operation may lead to breaches in the heat exchanger tubes separating the ammonia and seawater. Tests performed at Dow Chemical (Freeport, Texas) indicated that when minor amounts of ammonia were added to seawater, calcium carbonate formed on the heat exchanger surfaces. The Dow Chemical tests were conducted in a closed system. The residence time of the ammonia contaminated seawater in this system was approximately 100,000 times longer than that of seawater in the flow-through system that will be employed in an OTEC plant. It was, consequently, not possible to assess the significance of the Dow Chemical test results for OTEC heat exchanger performance. In order to determine if deposits will form on OTEC heat exchanger surfaces when ammonia leaks into seawater passing through test heat exchanger tubes, we have conducted a series of tests using a flow-through system. The results of these tests are the subject of this report.

C. Test Procedures and Results

1. Glass Tube Tests

Three series of tests were carried out. The first to be performed were the glass tube tests. Before proceeding to ammonia injection into metal tubes where the dynamics of the process would be hidden, we injected liquid ammonium hydroxide into a glass tube through which seawater was flowing. This test was also used to investigate liquid ammonium hydroxide as a medium for the simulation of an ammonia leak in a real OTEC heat exchanger.

The tests were carried out in a wet laboratory in the Collier building at the Kosenstiel School of Marine and Atmospheric Science (RSMAS). This laboratory is equipped with a PVC manifold supplying unfiltered nearsurface seawater taken directly from Bear Cut, an opening between Virginia Key and Key Biscayne connecting Biscayne Bay with the Atlantic Ocean. Unfortunately, this manifold was unable. to supply a flow rate greater than approximately $4.5 \mathrm{ft} / \mathrm{sec}$ through the one inch tube. In order to achieve the $6 \mathrm{ft} / \mathrm{sec}$ flow rate projected for the OTEC heat exchanger tubes, the seawater from the manifold was accumulated in a fifty gallon linear 
polyethylene barrel. Seawater from the barrel was pumped through a PVC ball valve into the glass tube. The flow was controlled with the valve to maintain a flow rate of $6 \mathrm{ft} / \mathrm{sec}$. The maximum duration of these tests was eight minutes; the time it took to bring the water level in the barrel down to the opening of the pump with the seawater manifold running constanty into the barrel.

The glass tube used in the test was a Pyrex tube of one inch I.D. and a test length of 36 inches between the injection tube and the downstream end of the tube. The injection tube was a short section of $8 \mathrm{~mm} \mathrm{O.D.} \mathrm{Pyrex}$ blown onto the large tube. Reagent grade, concentrated ammonium hydroxide was injected into the large tube through the injection tube. Injection rates were controlled using a gear driven syringe pump with a variety of drive speeds and syringes.

The test sequence began with the filling of the injection syringes and line with liquid ammonium hydroxide. With the barrel full of seawater, the water pump was turned on and when the pump line and glass tube were running and free of bubbles, the injector pump was turned on. When the barrel was nearly empty, the injector pump and water pump were stopped simultaneously. The glass tube drained within a few seconds from the downstream end. The tube was cleaned with concentrated HC1 between tests.

The ammonium hydroxide injection rates were adjusted to give concentrations of ammonia $\left(\mathrm{NH}_{3}\right)$ of $500,50,10$ and 5 parts per million by weight, assuming that the injected stream mixed completely with the seawater flowing through the large tube.

The results of the glass tube tests are summarized in Table 8 . In all four tests, ammonium hydroxide caused the rapid formation of a white precipitate on the interior of the tube. At a nominal $500 \mathrm{ppm} \mathrm{NH}{ }_{3}$ concentration, a long white spiral streak formed which ran the length of the 36 inch test section of the tube. The lack of downstream spreading and the spiral configuration of the streak indicated to us that the liquid ammonium hydroxide was not rapidly mixed with the seawater flowing through the tube and that it dominantly remained in the boundary layer on the tube walls, where it caused very high local concentrations of ammonium hydroxide with a resulting high $\mathrm{pH}$. Subsequent reduction of the injection rate to produce nominal ammonia concentrations of 50 and $10 \mathrm{ppm}$ yielded a precipitate streak with a different configuration. Scale deposition at these rates no longer 
TABLE 8

\section{RESULTS OF GLASS TUBE TESTS}

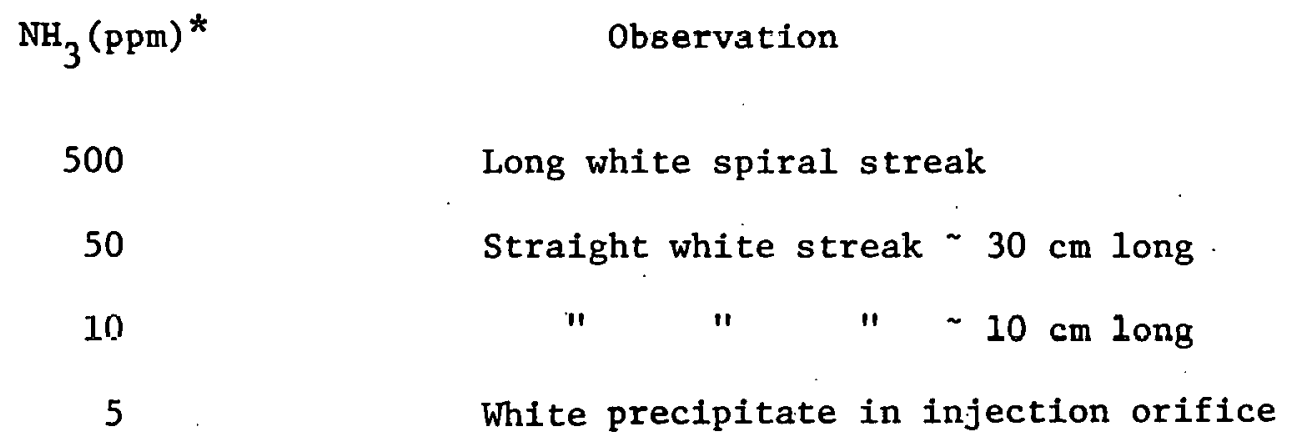

*Assuming complete mixing of $\mathrm{NH}_{4} \mathrm{OH}$ solution and seawater 
showed a spiral configuration and the streak spread slightly and became more diffuse downstream. The streak made at $50 \mathrm{ppm}$ was $30 \mathrm{~cm}$ long and is shown in Figure 2. At $10 \mathrm{ppm}$, the streak was only $10 \mathrm{~cm}$ long.

At 5 ppm nominal ammonia concentration, the precipitation of scale occurred within the injection port itself. Because it was not possible to run these tests for more than 8 minutes, it was not possible to determine whether or not the scale deposit could have healed over the orifice at this low injection rate. In no case did the white precipitate appear to grow significantly in the upstream direction.

The observation of streak formation indicated the incomplete mixing of the ammonium hydroxide solution with the flowing seawater. Since the liquid ammonia proposed as the working fluid for the OTEC heat exchanger can be expected to boil violently as a result of the pressure drop across a heat exchanger tube leak, and since the pressure differential will cause a much more violent injection than we could obtain with liquid ammonium hydroxide, we concluded that liquid ammonium hydroxide solution was not the appropriate medium for these tests if a true simulation of a leaking OTEC heat exchanger was going to be obtained. As a result, we decided to run tests on metal heat exchanger tubes by direct injection of liquid ammonia.

\section{Tube Aging Tests}

In order to compare scale formation in new heat exchanger tubes with the same process in tubes which had been "aged" in flowing seawater, nine 28 inch segments of heat exchanger tubes were exposed to flowing Bear Cut seawater. The tubes were exposed in groups of three in series on the PVC manifold in the Collier building. The three tubes were isolated by twelve inch sections of one inch I.D. vinyl (Tygon) tubing. The flow rates through the tubes, were approximately $4.5 \mathrm{ft} / \mathrm{sec}$.

Three aluminum tubes were "aged" for 117 hours. A second group of one titanium, one stainless steel and one copper/nickel tube was "aged" for 95 hours and a third group of the same composition was "aged" for 165 hours. The 95 hour "aged" tubes were used in the liquid ammonia injection tests. The remainder were visually inspected and saved for the stagnant seawater nucleation tests. Results on "aged" tubes are presented in the sections on liquid ammonia inejction and stagnant tests. 


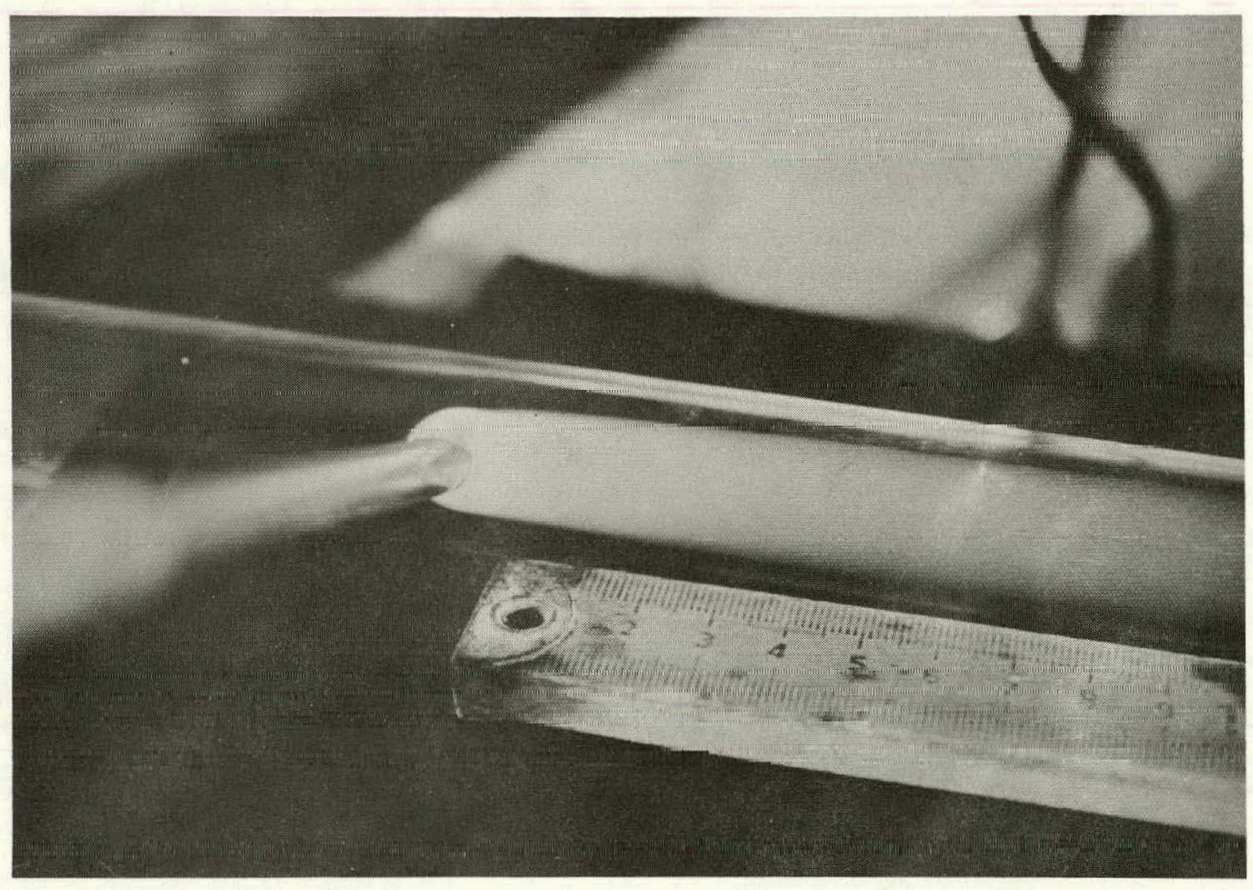

Figure 2. Scale streak formed on glass tube. Scale in $\mathrm{cm}$. 


\section{Ammonia Injection Tests}

In order to more accurately simulate a leaking OTEC heat exchanger tube, a test stand was constructed to allow the direct injection of ammonia. Because of the high reactivity of ammonia, and the relatively high pressures necessary to condense liquid ammonia at room temperatures, it was deemed unwise to attempt to insert a flow metering device into the injection line. We decided to use the hole drilled in the heat exchanger tube wall as a flow limiting orifice and tabulate our results as a function of hole size. Because of the danger of ammonia leaks in a confined space, these tests were carried out on the RSMAS dock which projects 'out into Bear Cut, the same source of water as in the previous experiments.

A 200 liter ta:k of liquid ammonia with a dip tube extending to the bottom of the tank to ensure the extraction of liquid was set up on the dock, about five feet above the water. A one quarter inch copper tube was connected directly to the tank valve with a brass Swagelock tube-to-pipe thread fitting. No pressure regulator was used in the 1ine. A brass Swagelock tee and a brass ball valve were incorporated in the copper tube next to the tank fitting to permit venting of pressure from the tube in the event of an obstruction, and to vent excess ammonia remaining in the tube at the end of each run. The remaining tube was approximately ten feet long and terminated in a second Swagelock tube-to-pipe fitting.

A one inch I.D. brass Cajon ultra-torr vacuum union was modifed for these tests. The fitting was bored through to increase the diameter sufficiently to be an easy slip-fit over the heat exchanger tubes. Next, in internal annular groove was cut in the center of the fitting. A hole was drilled through to this groove from one flat of the outside hexagonal section and tapped for the pipe thread on the end of the copper tube connected to the ammonia tank.

In practice, the internal groove was centered over the injection hole drilled in the heat exchanger tube test section, and the ends of the fitting snugged up by hand to compress the o-rings at each end. Viton o-rings were employed and were found to react badly to ammonia. Frequent replacements were required. A schematic representation of the test set up is presented in Figure 3.

When the fitting was installed on the test section, the pump and ball 
Figure 3. Liquid ammonia leak testing apparatus.

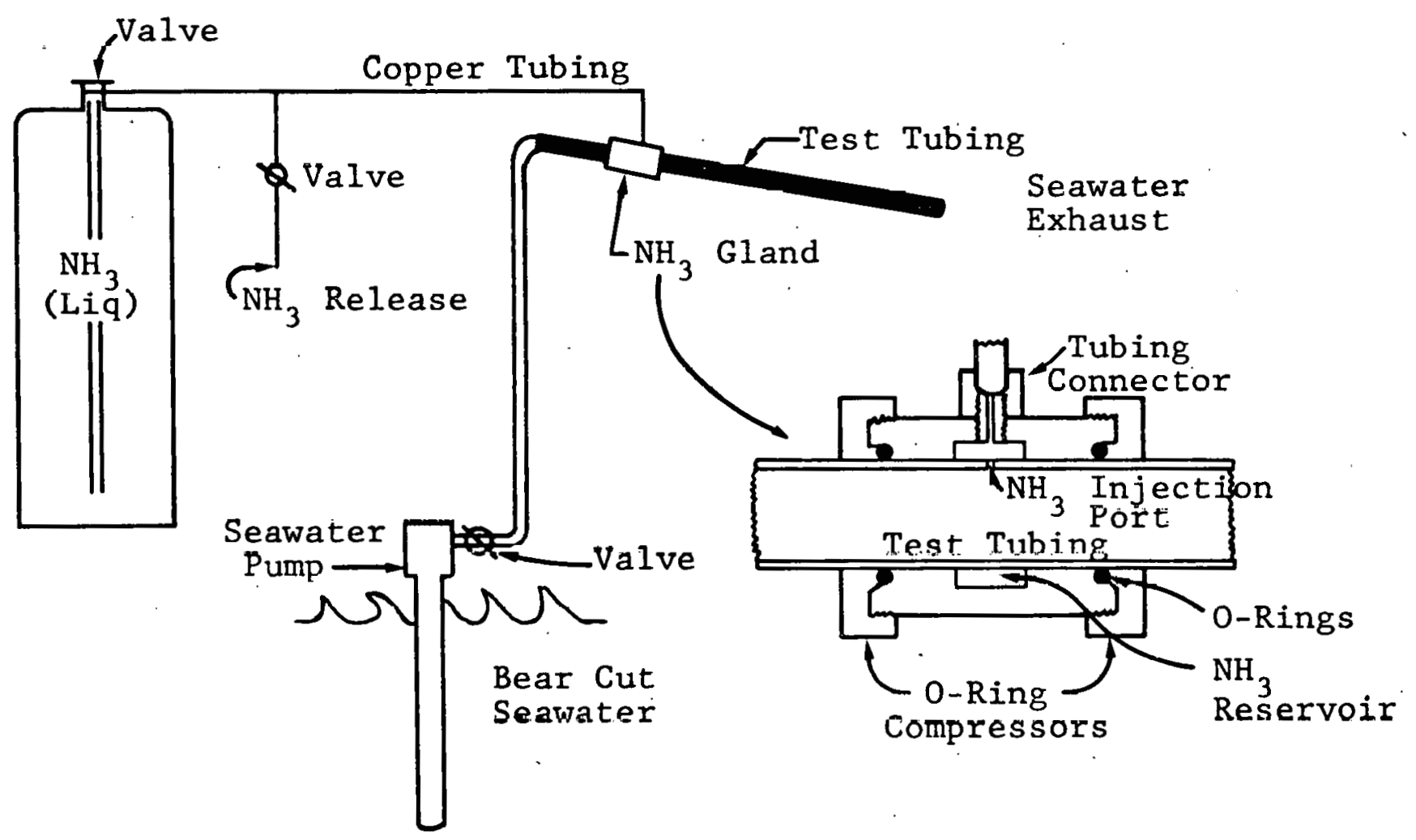


valve were attached with a short length of Tygon tubing and two hose clamps. The entire assembly of pump, ball valve, test section, fitting and copper tube was lowered until the intake end of the pump was submerged below the level of the troughs of the light chop generally present in the cut. The downstream end of the test section was kept above water level to prevent back flow due to wave action and to keep the interior of the test section dry until the pump was started.

To run a test the valve on the ammonia tank was opened and ammonia allowed to flow through the copper tube and fitting and into the test section. We started ammonia flow before water flow in order to prevent flooding of the fitting with the resulting formation of precipitate on the upstream side of the flow orifice.

With ammonia flowing, the water pump was switched on and the test timer started. To stop a run the procedure was reversed and the copper tube vented through the vent valve.

It is not clear whether or not liquid ammonia was present within the injection fitting. Since the flow was probably throttled by the hole in the test section, most of the pressure drop should occur there, and these tests should correspond very closely to an actual OTEC heat exchanger leak. If the pressure drop within the copper tube was sufficiently large, the ammonia in the tube might have been partially or completely boiled. Since the copper tube never appeared to be chilled (which would result if the liquid ammonia were boiling) we believe that liquid ammonia was present in the injection fitting. In either case, the injection of ammonia was much more violent in these tests than in the glass tube tests. No precipitate was ever found inside the fitting, and we conclude that no water ever backed up into the fitting.

Table 9 gives the parameters of the tests conducted. Runs B-1 through B-5 were conducted on clean (unaged) aluminum tubing. Fifteen minute tests on progressively amaller holes were conducted in runs B-1 through B-3. Since the 0.024 inch hole in run B-3 gave no immediately visible deposit, a sixty minute test on a standard length tube and a 40 minute test on a full length 10 foot section were run. The subsequent runs were run on "aged" test sections of normal length for 30 minutes with the exception of test B-9 which was a 60 minute run duplicating B-4 but using an "unaged" tube.

After resting, the sample tubes were air dried and cut into working 
TABLE 9

METAL TUBE TEST PARAMETERS*

\begin{tabular}{|c|c|c|c|c|c|}
\hline $\begin{array}{c}\text { Run } \\
\text { Number }\end{array}$ & $\begin{array}{l}\text { Tube } \\
\text { Length }\end{array}$ & $\begin{array}{l}\text { Hole } \\
\text { Size }\end{array}$ & $\begin{array}{l}\text { Duration } \\
\text { (min) }\end{array}$ & \multicolumn{2}{|c|}{$\begin{array}{c}\text { Tule } \\
\text { Material }\end{array}$} \\
\hline B-1 & $2^{\prime}$ & $0.0625^{\prime \prime}$ & 15 & \multicolumn{2}{|c|}{ Al clean } \\
\hline $\mathrm{B}-2$ & $2^{\prime}$ & $0.0310^{\prime \prime}$ & 15 & " & $"$ \\
\hline$B-3$ & $2^{\prime}$ & $0.0240^{\prime \prime}$ & 15 & $"$ & $"$ \\
\hline$B-4$ & $2^{\prime}$ & $"$ & 60 & $"$ & $"$ \\
\hline$R-5$ & $10^{\prime}$ & $0.0250^{\prime \prime}$ & 40 & $"$ & $"$ \\
\hline$B-6$ & $2^{\prime}$ & $"$ & 30 & $\mathrm{Cu} /$ & Ni aged \\
\hline B-7 & $2^{\prime}$ & $"$ & 30 & SS & " \\
\hline$B-\dot{8}$ & $2^{\prime}$ & " & 30 & Ti & " \\
\hline B-9 & $2^{\prime}$ & $"$ & $60^{\circ}$ & $\mathrm{A} 1$ & $"$ \\
\hline B-10 & $2^{\prime}$ & " & 30 & $\mathrm{Al}$ & $"$ \\
\hline
\end{tabular}

*Tubes were 1 inch nominal inside diameter with a wall thickness of approximately 0.05 inches 
samples (see Figure 4). Visual ovservations of the tubes before drying, especially B-1 which used the largest hole, indicate that the precipitate formed was, a soft, creamy, white gel. Subsequent estimations of scale thickness should take into account that water contents of wet samples were probably much higher and thickness consequently greater before drying. The cleanability of these soft deposits may be considerably greater than their dried equivalent.

Several features are visible on the dried sections. First, there is generally a darkened spot on the tube wall exactly opposite the leak. It is not clear what the cause of this spot is, but direct impingement of the liquid ammonia on this spot occurs immediately before the water flow begins. It may also be possible for the injected ammonia to completely cross the water stream during a run. We consider this a less likely explanation.

Another observation is that scale deposition does not occur at the leak site. In the glass tube tests, scale was deposited around the injection port. In these tests scale deposition generally begins downstream and on the opposite side of the tube from the leak orifice. Figure 5 shows the injection orifice region of tube B-9. A streamlined streak can be seen attached to the tube surface starting about $4 \mathrm{~cm}$ downstream of the injection orifice. The dark spot opposite the injection site is also visible in this figure. In test B-1 with its large .0625 inch hole, a very heavy deposit was formed around the entire circumfrence of the test section, but downstream of the hole. Figure 6 shows the injection region of this tube.

A final visual observation is the there appears to be a significant difference in the scale deposition in "aged" and "unaged" tubes. Figure 7 shows downstream sections from tests B-4 and B-9. Both tests were 60 minute runs with small holes ( 0.024 and 0.025 inches respectively) but B-4 was a clean tube and B-9 had been aged for 117 hours. The spiral streak which started near the orifice in B-9 of still present and visible on the tube wall seven inches farther down the tube. No streak is visible in B-4 which was run under identical cond1tions but with "unaged" tube.

Table 10 shows the results of chemical analyses of the water soluble and acid soluble portions of tube precipitates. Precipitate was scraped from dry tube sections. Table 11 shows the carbon dioxide content of the same sámples in weight percent. A powder from tube B-5 was oven dried at $350^{\circ} \mathrm{C}$ for 45 minutes. The bound water calculated from weight 1 oss was $33 \%$. 
Figure 4. Tube sectioning scheme.

2-FOOT SECTIGNS, Al, SS, Ti, Cu,Ni

Injection Port

SEM Samples

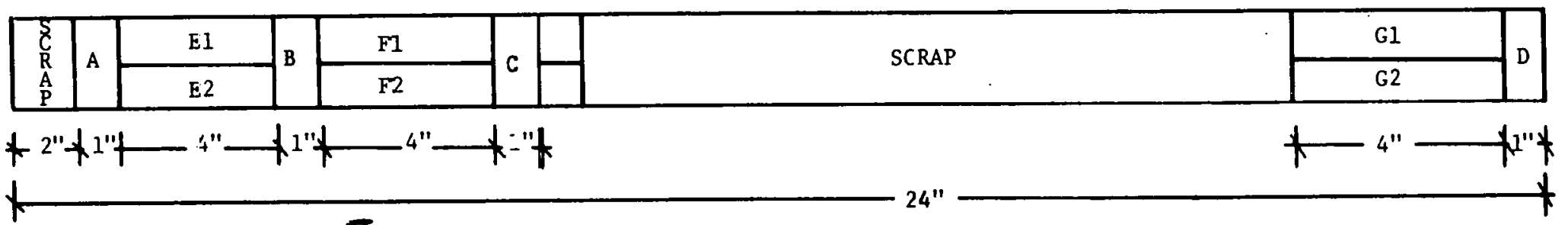

SAMPLE LABELING: BIE1 $\left\{\begin{array}{l}\text { B }=\text { SERIES } \\ 1=\text { PIPE NC. } \\ \text { E1 }=\text { PIPE SECi. NO. }\end{array}\right.$

10- FOOT SECTION, A1

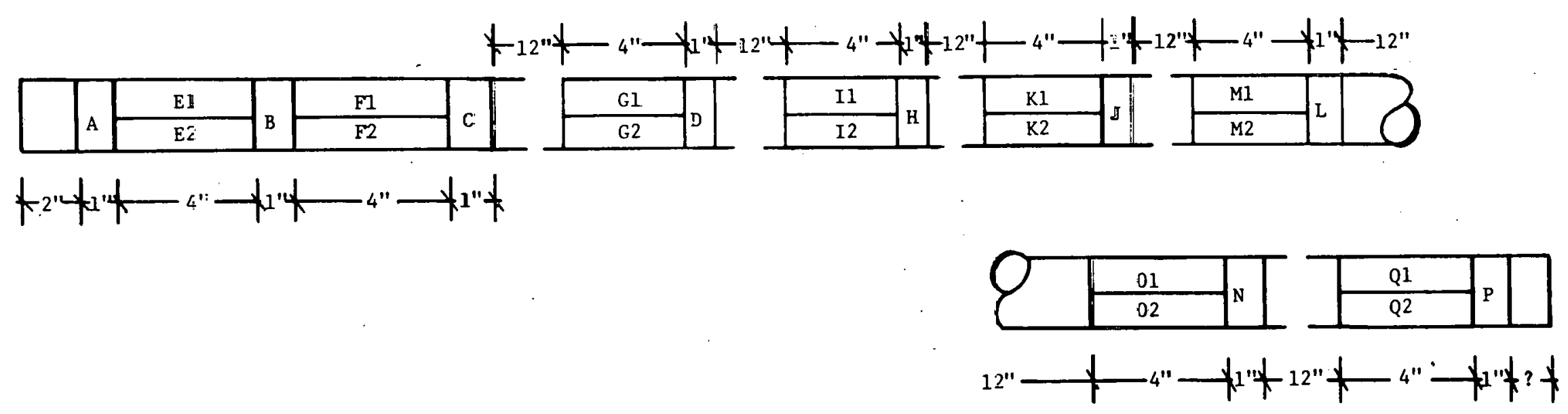




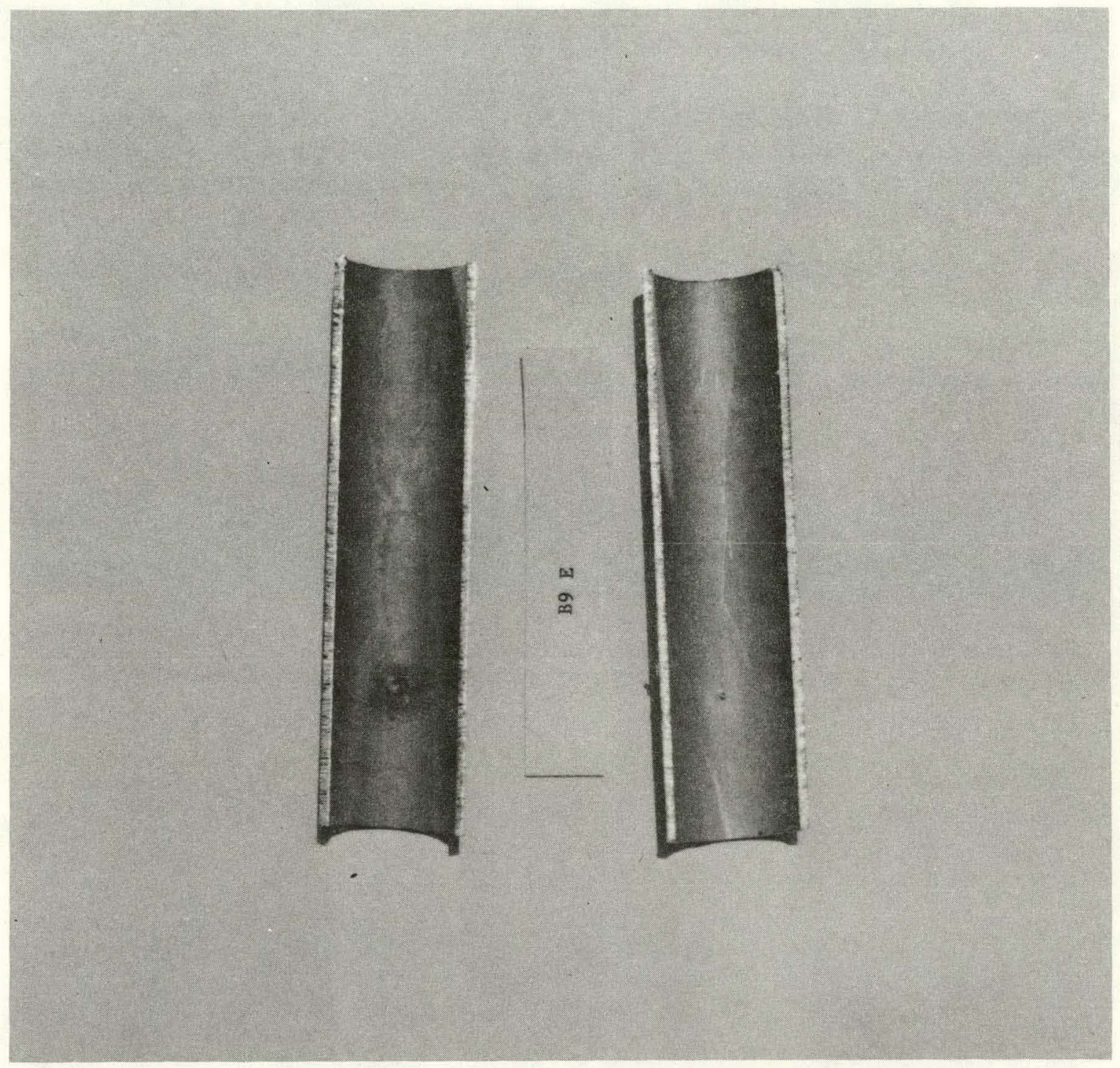

Figure 5. Injection Region of Tube B-9. 


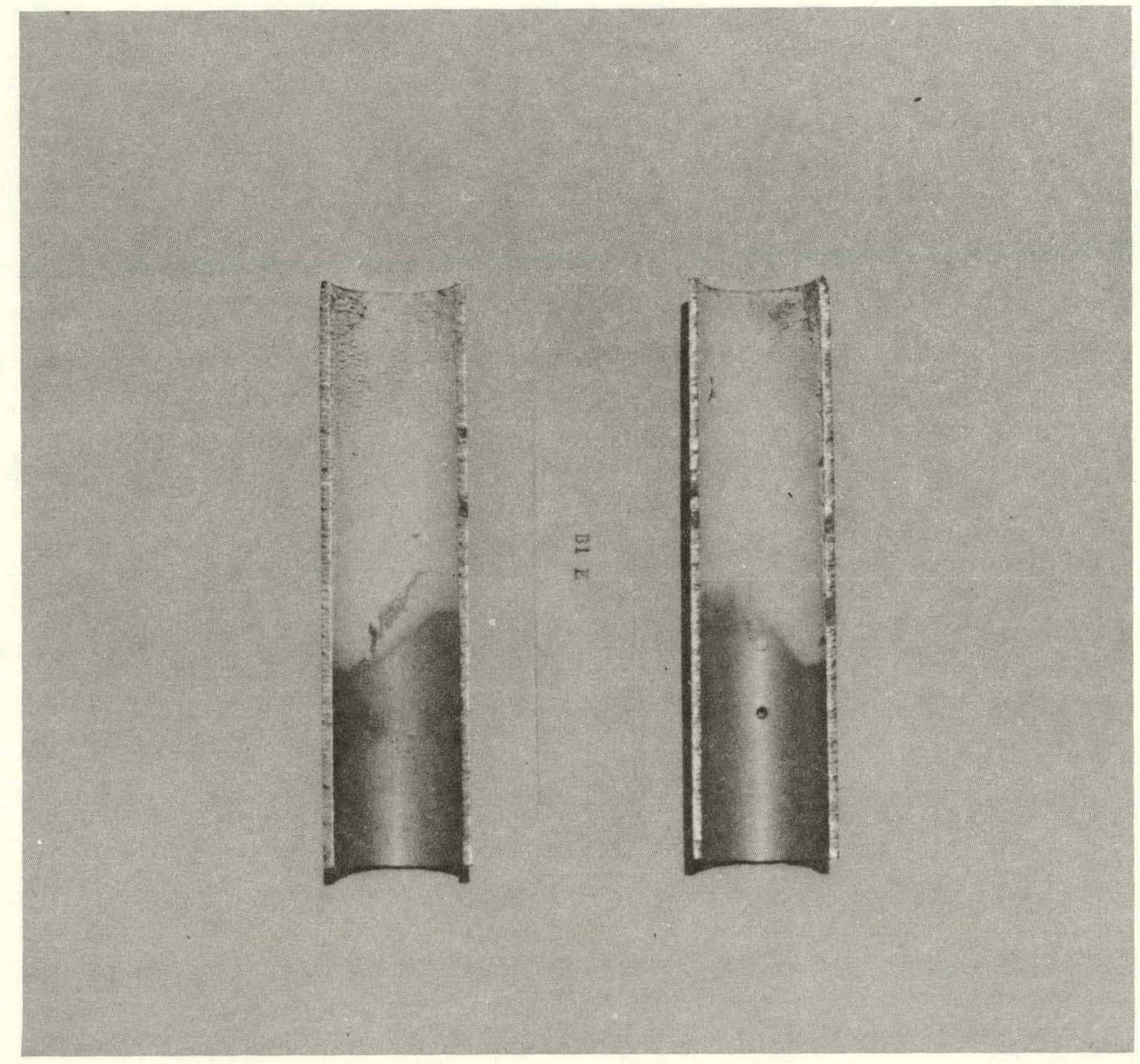

Figure 6. Injection Region of Tube B-1. 

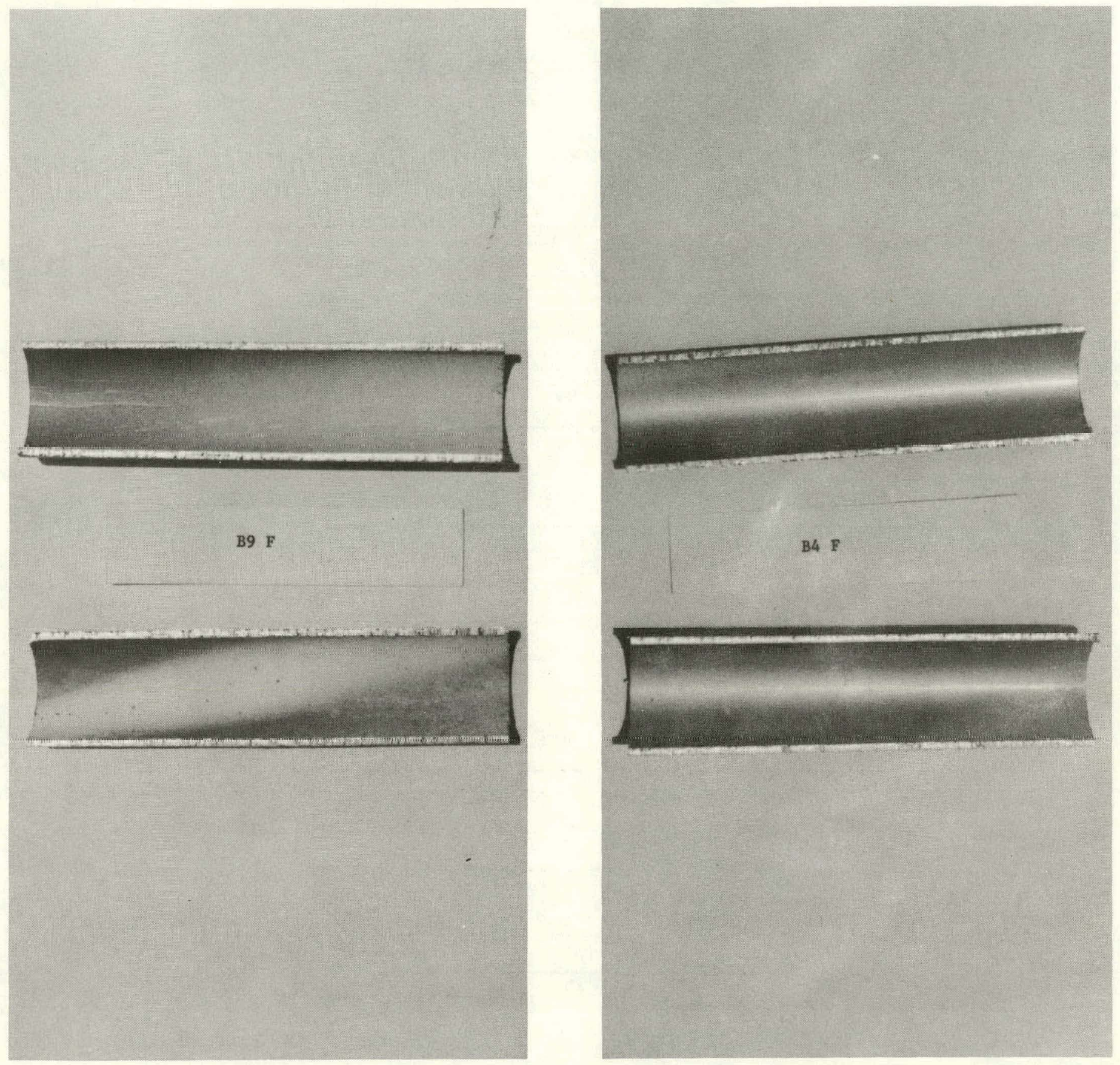

Figure 7. Down Stream Sections of Tubes B-4 and B-9. 
TABLE 10

SCALE COMPOSITION

Table 10A. Water Soluble Component

\begin{tabular}{cccccc}
$\begin{array}{c}\text { Sample } \\
\text { No. }\end{array}$ & $\mathrm{Mg}$ & $\mathrm{Ca}$ & $\mathrm{Na}$ & $\mathrm{K}$ & $\mathrm{Na} / \mathrm{K}$ \\
$\mathrm{Bla}$ & 32710 & 682 & 52710 & 2794 & 18.9 \\
$\mathrm{Blb}$ & 51020 & 1276 & 51280 & 2577 & 19.9 \\
\hline B2a & 80820 & $31 / 2$ & $4 / 380$ & 2002 & 23.8 \\
B2b & 80750 & 2463 & 38360 & 1817 & 21.1 \\
\hline B6a & 62720 & 4508 & 45080 & 1960 & 23.0 \\
\hline B6b & 79730 & 5024 & 45870 & 2021 & 22.7 \\
\hline B10a & 98740 & 4488 & 31420 & 1683 & 18.7 \\
B10b & 111270 & 3948 & 19740 & 1346 & 14.7 \\
\hline
\end{tabular}

Table 10B. Acid Soluble Component

\begin{tabular}{ccccc}
$\begin{array}{c}\text { Sample } \\
\text { No. }\end{array}$ & Mg & Ca & Na & K \\
B1a & 48230 & 2794 & 393 & nd \\
B1b & 113270 & 3903 & 357 & " \\
\hline B2a & 135950 & 2719 & nd & nd \\
B2b & 116280 & 3795 & " & " \\
\hline B6a & 100000 & 2450 & nd & nd \\
B6b & 92800 & 2621 & " & " \\
\hline B10a & 124100 & 2450 & nd & nd \\
B10b & 106400 & 1436 & " & " \\
\hline
\end{tabular}


TABLE 11. CARBON DIOXIDE CONTENT OF SCALE

$\begin{array}{ll}\begin{array}{c}\text { Sample } \\ \text { No: }\end{array} & \begin{array}{c}\text { Wt\% } \\ \mathrm{CO}_{2} \\ \text { B2c total }\end{array} \\ 25 \\ \text { B2c acid soluble } & 23 \\ \text { B6c total } & 23 \\ \text { B7c total } & 28 \\ \text { B8c total } & 24 .\end{array}$

TABLE 12. WEIGHT CONCENTRATION OF SCALE COMPONENTS Total Solids Sea Salt Salt Free

\begin{tabular}{cccc}
$\mathrm{Mg}$ & $17.50 \%$ & $0.50 \%$ & $17.00 \%$ \\
$\mathrm{Ca}$ & $0.65 \%$ & $0.17 \%$ & $0.48 \%$ \\
$\mathrm{Na}$ & $4.50 \%$ & $4.50 \%$ & - \\
$\mathrm{K}$ & $0.20 \%$ & $0.20 \%$ & - \\
$\mathrm{CO}_{2}$ & $25.00 \%$ & - & $25.00 \%$ \\
$\mathrm{H}_{2} \mathrm{O}$ & $33.30 \%$ & - & $33.00 \%$ \\
$\mathrm{Cl}$. (calculated) & $\underline{8.10 \%}$ & \\
\multicolumn{2}{c}{ Total Sea Salt } & $13.47 \%$ &
\end{tabular}

TABLE 13. SALT FREE COMPONENTS AS OXIDES

$\begin{array}{lcc} & \text { Wt\% } & \text { Millimoles/g } \\ \mathrm{MgO} & 28.20 & 6.99 \\ \mathrm{Ca} 0 & 0.67 & 0.12 \\ \mathrm{CO}_{2} & 25.00 & 5.68 \\ \mathrm{H}_{2} \mathrm{O} & \underline{33.30} & 18.50 \\ \text { Total oxides } & 87.17 & \cdots\end{array}$


Powder method X-ray diffractograms were run on ten samples of powder. The only diffraction peaks detected were those of halite ( $\mathrm{NaC1}$ ).

Table 12 below shows an estimate of the typical weight concentrations of the components measured, an estimate of the sea salt contribution to these quantities; including chlorine calculated from the sodium value, and the resulting salt free concentrations of $\mathrm{Mg}, \mathrm{Ca}, \mathrm{CO}_{2}$ and $\mathrm{H}_{2} \mathrm{O}$. Table 13 shows the concentration of the salt free components recalculated as oxides in weight percent and in millimoles per gram. The sum of the weight concentrations including sea salt is $100.6 \%$ fortuitously good for such rough eslinales.

The phase composition of the precipitate was estimated by combining all of the $\mathrm{CaO}$ with $\mathrm{CO}_{2}$ to form $\mathrm{CaCO}_{3}$; combining the remaining $\mathrm{CO}_{2}$ with $\mathrm{MgO}$ and $3 \mathrm{H}_{2} \mathrm{O}$ to make nesquehonite $\left(\mathrm{MgCO}_{3} \cdot 3 \mathrm{H}_{2} \mathrm{O}\right)$; and combining the remaining $\mathrm{MgO}$ with $\mathrm{H}_{2} \mathrm{O}$ to make $\mathrm{Mg}(\mathrm{OH})_{2}$. The resulting composition is given in $\mathrm{Table} 14$ and shown schematically in Figure 8 . The calculated composition accounts for all of the $\mathrm{CaO}, \mathrm{MgO}$ and $\mathrm{CO}_{2}$ and $98 \%$ of the $\mathrm{H}_{2} \mathrm{O}$ in the analysis. Since the phases actually present in the precipitate are $\mathrm{X}$-ray amorphous, they are probably sub- to non-stoichiometric mixed phases. The dominance of magnesium compounds in the salt free precipitate is notable. The $\mathrm{Mg} / \mathrm{Ca}$ ratio in the salt free precipitates is more than ten times higher than in seawater.

\section{SEM Observations}

The deposits formed on pre-"aged" segments of copper-nicke1, stainless steel, titanium and aluminum heat exchanger tubes are shown in Figure 9-12 respectively. In each case the leak hole size was 0.025 inches, seawater flow rate was 6 feet per second and exposure time 30 minutes. Tube segments for SEM photography were cut from the tube nine inches downstream from the ammonia injection port (see Figure 4).

Figure 9 ehowe the depocit formed of eample B-6, an "aged" copper= nickel tube. These deposits are ten to fifty micron diameter clumps of sub-micron size crystallites. In this tube, the clumps have a fragile dendritic appearance and are quite densely packed on the tube surface. The morphology of theee deposite repreacnte the arrangement of scale after drying and the original distribution may have been quite different. Figure 10 shows the deposits formed on an "aged" stainless steel 
TABLE 14. ESTIMÁTED SCALE COMPOSITION

\begin{tabular}{lll}
\multicolumn{1}{l}{ Phase } & & $\mathrm{mM} \mathrm{g}^{-1}$ \\
$\mathrm{CaCO}_{3}$ & & 0.12 \\
$\mathrm{MgCO}_{3} \cdot 3 \mathrm{H}_{2} \mathrm{O}$ & & 5.56 \\
$\mathrm{Mg}(\mathrm{OH})$ & & 1.43 \\
$\mathrm{H}_{2} \mathrm{O}$ (remainder) & & 0.39
\end{tabular}


Figure 8 .

\section{LIQUID AMMONIA INDUCED \\ SCALE COMPOSITION \\ (Air Dried)}

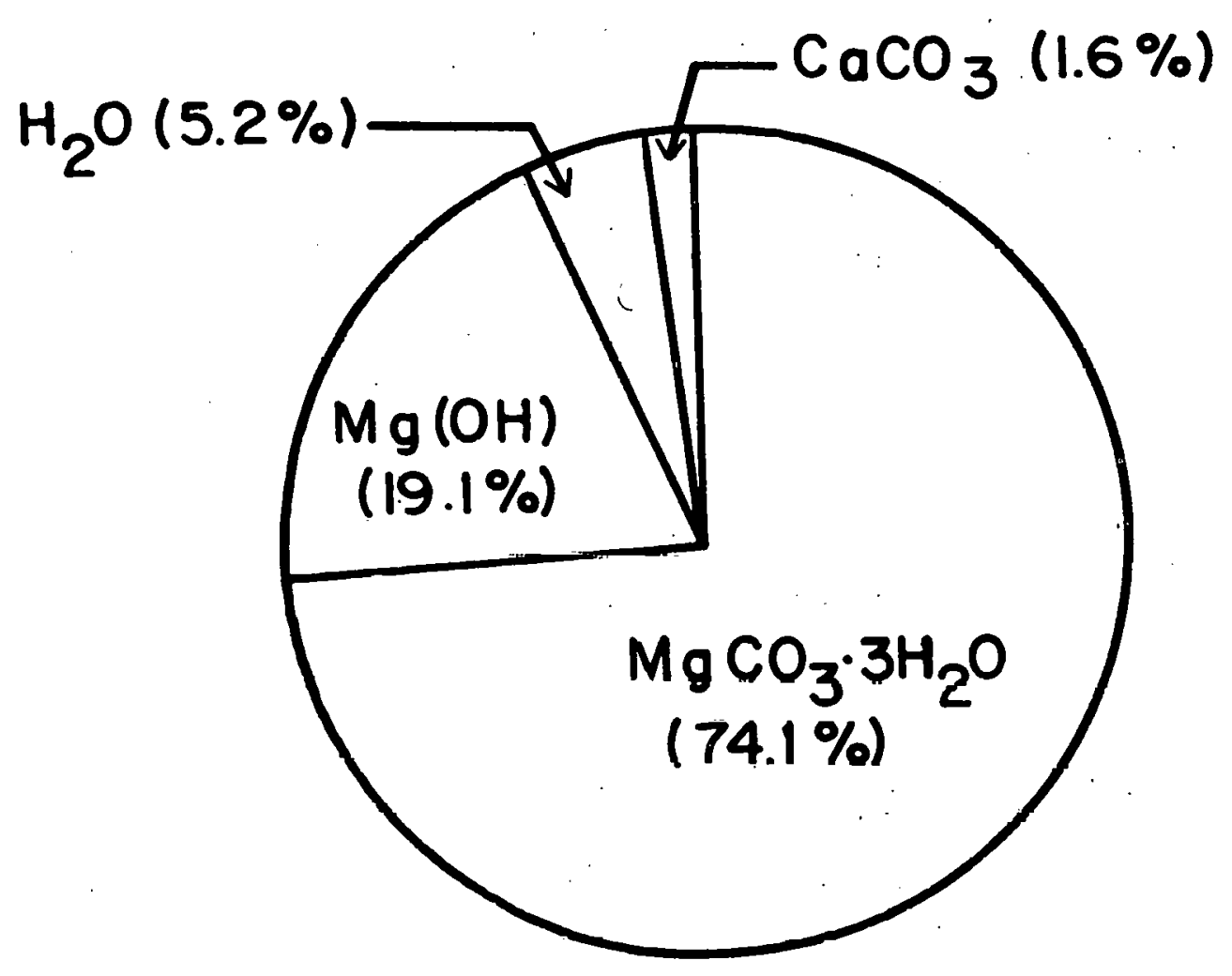



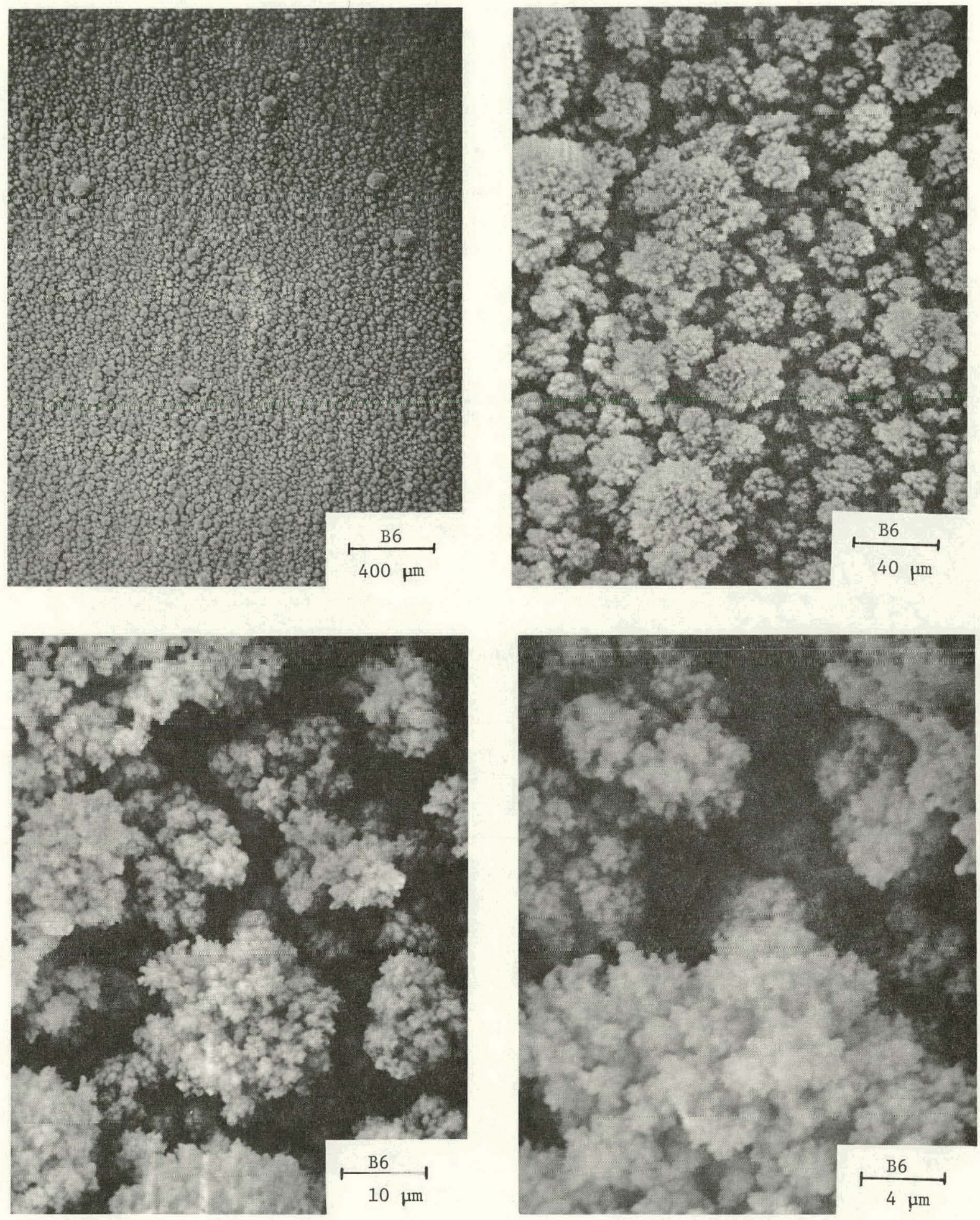

Figure 9. SEM picture of "aged" copper-nickel tube surface after liquid ammonia injection. 

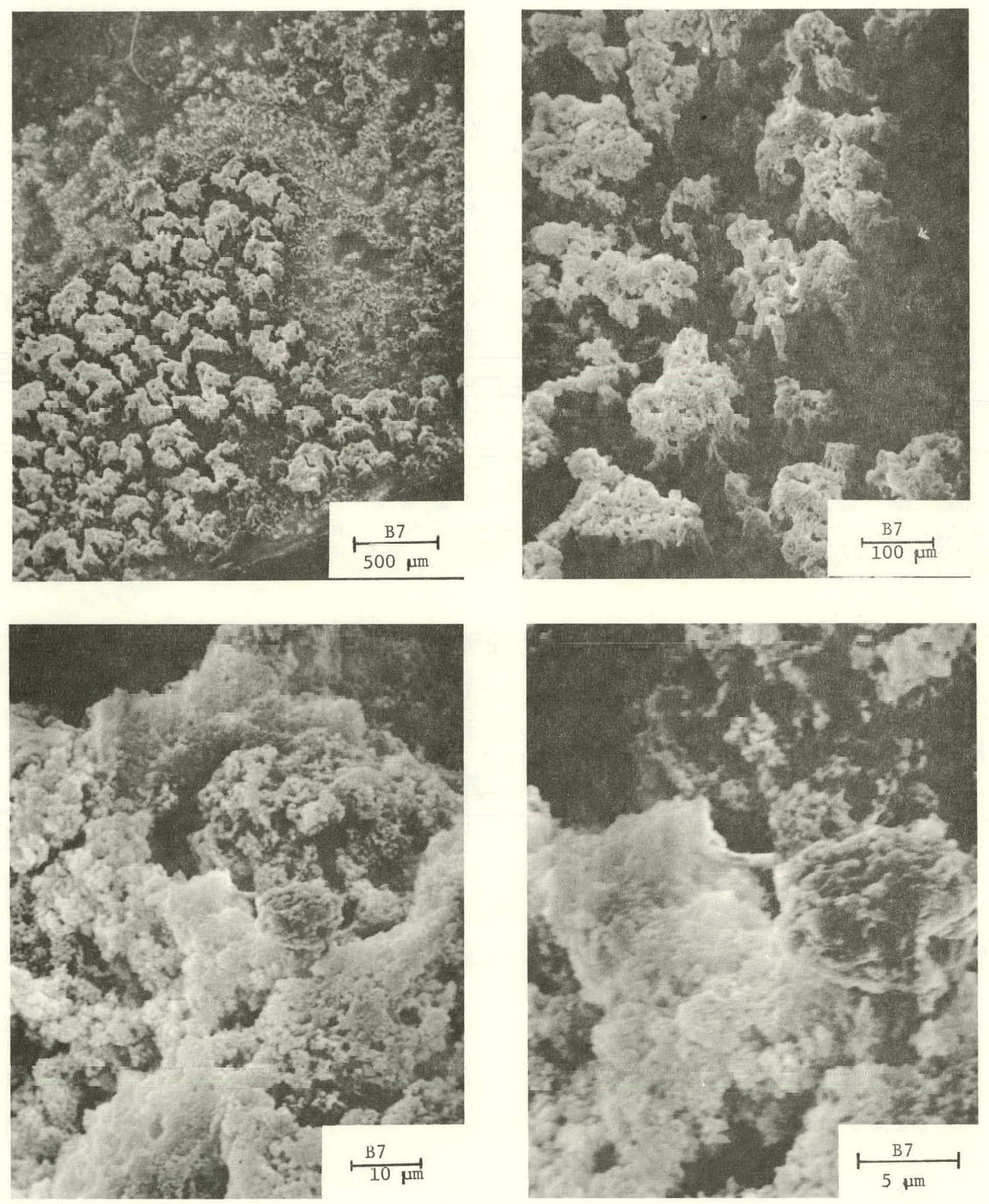

Figure 10. SEM picture of "aged" stainless steel tube surface after liquid ammonia injection. 
surface. These deposits are also clumps but about five times larger. The density of clumps is lower than in Figure 9 and some areas are free of clumps or have patterns suggesting either incipient clump growth, or the roots of previous clumps which have been destroyed. At higher magnification, these structures also appear to be composed of sub-micron sized crystallites, but they are arranged in a dense, solid looking structure. These structures suggest that some combination of erosive and compacting processes are at work. They are quite different from the fragile, dendritic appearance of the deposits in Figure 9.

Figure 11 shows the deposits on an "aged" titanium surface. The density and size of the clumps in this deposit lie between the small abundant structure in Figure 9 and the large but more scarce clumps in Figure 10. In addition, there is an indication, in the higher magnification photographs, of layering and pitting within the clumps. The fine crystallites appear to be as densely packed as those in Figure 10, but there appear to be numerous flat surfaces containing equidimensional pits less than one micron in diameter.

Figure 12 shows the deposit formed on the "aged" aluminum tube B-10. This deposit is quite similar to the deposit shown in Figure 9. A heavy deposit of 10 to 50 micron clump composed of sub-micron crystallites. At high magnification, the structure in Figure 12 is somewhat less fragile looking with a cauliflower head texture. There is little suggestion of layering, pitting or erosion in this deposit.

In general, it appears that the nature of the deposit formed during ammonia injection depends on the substrate material. It is not clear whether the characteristics shown in these photographs are artifacts of the drying process or represent real variations in deposition, attachment and erosion characteristics of the scale deposited on different surfaces under identical conditions.

\section{Conclusions}

These tests have demonstrated that massive calcium carbonate deposits are not formed in OTEC heat exchanger tubes during short duration exposure to ammonia leaks in flowing seawater. In a one hour test almost one fifth of a pound of inorganic carbon passed through the tube. This is sufficient to form about $1.7 \mathrm{lbs}$. of $\mathrm{CaCO}_{3}$ if completely converted to carbonate ion by the $\mathrm{pH}$ increase due to ammonia addition. There is also enough magnestum 

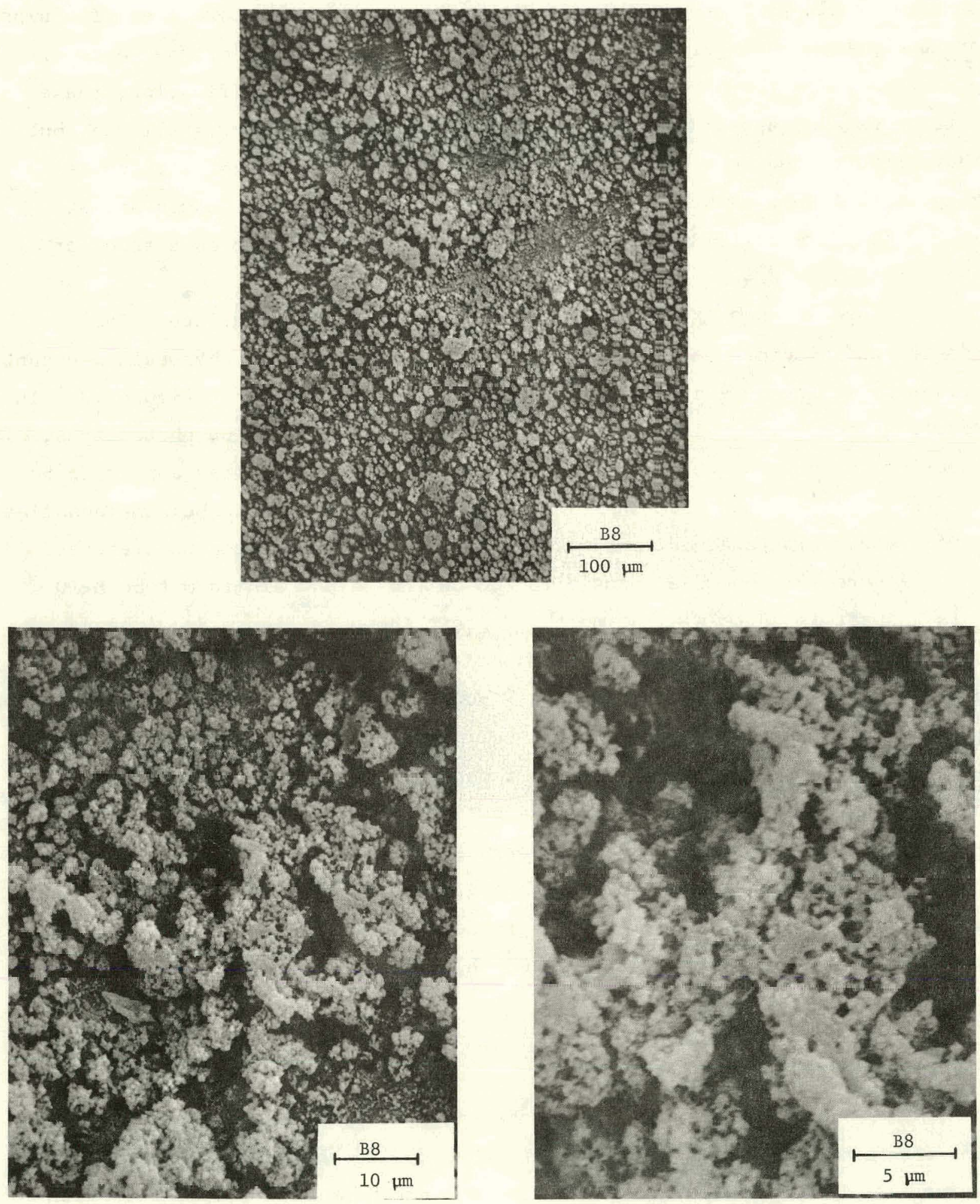

Figure 11. SEM picture of "aged" titanium tube surface after liquid ammonia injection. 

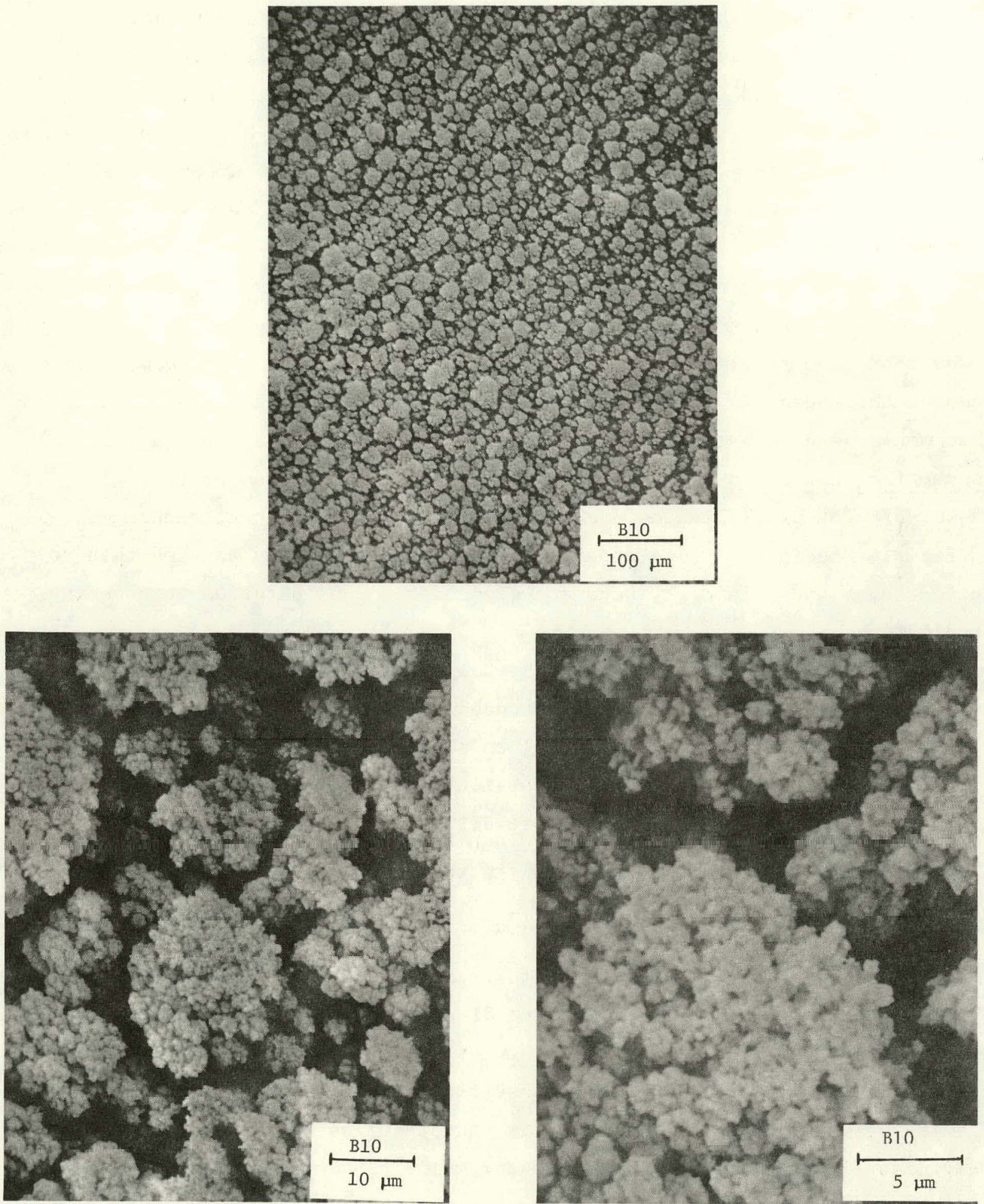

Figure 12. SEM picture of "aged" aluminum tube surface after liquid ammonia injection. 
passing through the system to make almost 24 pounds of $\mathrm{Mg}(\mathrm{OH})_{2}$ if the $\mathrm{pH}$ becomes sufficiently high. Scale deposition in these tests are vastly less than these theoretically possible quantities. The rapid dilution of the injected ammonia and the difficulty of attaching most of the particles formed probably preclude massive deposits in systems with high flow rates and short residence times. It is also clear, however, that an ammonia leak in a heat exchanger whose water flow has been stopped may have very serious consequences.

These tests have also demonstrated that ammonia leaks through holes as sma $\perp$ as $U . U 24$ inches do result in large depos1ts of magnesium Lich depusits downstream from the leak. These deposits are thick, soft and creamy when wet and the thickness of the deposits when wet is probably considerably thicker than would be calculated from the composition data given above and the assumption that a non-porous layer was formed. It may also be true that these soft wet precipitaates are easily cleaned from the heat exchanger surfaces. Precipitate also appears to attach more readily to aged than to unaged tubes and this might become a significant consideration in cleaning studies.

Finally, the results obtained by Dow Chemical indicate that transformation to $\mathrm{CaCO}_{3}$ may occur upon extended expusure lu seawater. The con version of nesquehonite $\left(\mathrm{MgCO}_{3} \cdot 3 \mathrm{H}_{2} \mathrm{O}\right)$ to a calcium carbonate might proceed rather easily in seawater. The conversion of the 19 percent of brucite $\left(\mathrm{Mg}(\mathrm{OH})_{2}\right)$ to a carbonate might be more difficult.

\section{STAGNANT SEAWATER NUCLEATION TESTS}

\section{A. Summary}

Tests were conducted using Gulf Stream seawater sealed in candidate OTEC heat exchanger tubes to determine if calcium carbonate nucleation would occur on tube surfaces exposed to stagnant seawater for extended periods of time. The results are similar to those found in the GOME II tests under flowing seawater conditions. Titanium and stainless steel tubes exhibited only minor interaction with the seawater while aluminum and copper-nickel tubes interacted strongly with the seawater. The dominant scale component on the aluminum tube surfaces is an aluminum compound, probably aluminum hydroxide. A chloro-hydroxide copper compound formed on the copper-nickel tube surfaces. The formation of the scale product on the aluminum tube 
surfaces is initially rapid, with approximately two thirds of the scale present after 30 days exposure being formed in one day or less.

The concentrations of magnesium and calcium on the surfaces of titanium and stainless steel tubes are close to those which can be accounted for by sea salt left by evaporation of adhering seawater. On aluminum tube surfaces both calcium and magnesium are present at concentrations significantly greater than what can be accounted for by sea salt. Magnesium is significantly enriched relative to calcium when compared with their ratio in seawater. Magnesium concentrations on copper-nickel tube surfaces are generally very low. On the copper-nickel tube surfaces, exposed to stagnant seawater at $3^{\circ} \mathrm{C}$, the calcium concentrations are similar to those found on aluminum tube surfaces, but on the copper-nickel tube surfaces exposed to seawater at $22^{\circ} \mathrm{C}$, the calcium concentrations are approximately 10 times greater than found on aluminum tube surfaces. The results indicate that calcium carbonate may nucleate on aluminum and copper-nickel tube surfaces exposed to stagnant seawater.

B. Introduction

It is possible that, during the operation of an OTEC plant, the flow of seawater through the heat exchangers may be interrupted. If this occurs stagnant seawater remaining in the heat exchangers may alter the corrosion mechanisms from those found under flowing seawater conditions. Under these conditions the seawater in the heat exchanger tubes may become significantly more supersaturated with respect to calcium carbonate and calcium carbonate scale may be nucleated on the heat exchanger surfaces. In order to gain a better understanding of the processes that occur under stagnant seawater conditions, candidate OTEC heat exchanger materials were exposed to stagnant seawater for various periods of time at $3^{\circ}$ and $23^{\circ} \mathrm{C}$, and the chemistry of the resulting scale deposits determined.

\section{Test Procedures}

Aluminum, copper-nicke1, AL6X stainless steel and titanium tubes were cleaned, etched and "aged" by the procedures described in the Ammonia Leakage Test Procedures section of this report.

Freshly collected Gulf Stream seawater was used as the stagnant seawater medium. Its saturation state was adjusted by the addition of acid (HC1) or 
base $(\mathrm{NaOH})$, and equilibrated with air. Nutrient analyses were performed by the standard methods of Strickland and Parsons (1972). Total alkalinity and calcium concentrations were determined by the methods described by Gieskes (1974). Saturation states, with respect to calcite, were calculated by the methods described in the Calcite and Aragonite Powder Growth Rate Tests section of this report.

After preparation and analysis the seawater was sealed into $15 \mathrm{~cm}$ sections of tube samples using Parafilm and rubber bands. This was done with overlying air being excluded. The tubes were stored in a vertical position during exposure to stagnant seawater. Test conditions are summarized in Table 15.

After exposure to the stagnant seawater the tubes were drained and given a quick rinse with double distilled water to remove excess adhering seawater. On some tests the seawater $\mathrm{pH}$, alkalinity and dissolved trace metal content were determined. The tubes were then cut into sections for the different analyses (see Figure 13). The inorganic scale composition was determined by the methods described in the GOME II inorganic Scale Chemistry Test Procedures section of this report. Blank values determined on tubes not exposed to seawater were sufficiently low, so that no corrections of absolute concentrations were necessary. An attempt was made to scrape the scale deposits off the tubes for X-ray diffraction analysis. On most of the tubes there was insufficient scale for X-ray diffraction analysis. Scanning electron photomicrographs were made of representative samples of the tubes.

\section{Results}

The results of the analyses of the seawater chemistry prior to its exposure to the tubing samples are presented in Table 16. The results of the seawater chemistry determinations after exposure to the tubing samples are presented in Tables 17 and 18.

The $\mathrm{pH}$ and total alkalinity of the seawater exposed to the aluminum tube samples for 30 days decreased in the samples kept at $22^{\circ} \mathrm{C}$ and increased in the samples kept at $3^{\circ} \mathrm{C}$. Total alkalinity decreased in all other tube eamples exposed to seawater for 30 daye, except one copper-nickel tube where it increased. In the stainless steel and titanium tubes $\mathrm{pH}$ decreased at $22^{\circ} \mathrm{C}$ and increased at $3^{\circ} \mathrm{C}$. $\mathrm{pH}$ increased in all copper-nickel tubes.

Dissolved aluminum concentrations in seawater exposed to aluminum tubing 
TABLE 15

STAGNANT SEAWATER NUCLEATION TEST CONDITION

\begin{tabular}{|c|c|c|c|c|c|}
\hline $\begin{array}{l}\text { Tube } \\
\text { Sample }\end{array}$ & $\begin{array}{l}\text { Tube } \\
\text { Type }\end{array}$ & $\begin{array}{c}\text { Temperature } \\
\left({ }^{\circ} \mathrm{C}\right)\end{array}$ & $\frac{\mathrm{IMP}}{\mathrm{K}_{\mathrm{c}}{ }^{\prime}}$ & $\begin{array}{c}\text { Exposure } \\
\text { (Days) }\end{array}$ & Replicate \\
\hline 1 & Al & 22 & 1 & 1 & 1 \\
\hline 2 & Al & 22 & 1 & 1 & 2 \\
\hline 3 & A1 & 22 & 6 & 1 & 1 \\
\hline 4 & $\mathrm{~A} 1$ & 22 & 6 & 1 & 2 \\
\hline 5 & Al & 22 & 7 & 1 & $i$ \\
\hline 6 & Al & 22 & 7 & 1 & 2 \\
\hline 7 & Al & 22 & 1 & 7 & 1 \\
\hline 8 & $\mathrm{Al}$ & 22 & 1 & 7 & 2 \\
\hline 9 & AI & 22 & 6 & 7 & 1 \\
\hline 10 & $\mathrm{Al}$ & 22 & 6 & 7 & 2 \\
\hline 11 & $\mathrm{Al}$ & 22 & 7 & 7 & 1 \\
\hline 12 & Al & 22 & 7 & 7 & 2 \\
\hline 13 & $\dot{\mathrm{A}} 1$ & 22 & 1 & 30 & 1 \\
\hline 14 & $\mathrm{Al}$ & 22 & 1 & 30 & 2 \\
\hline 15 & Al & 22 & 6 & 30 & 1 \\
\hline 16 & $\mathrm{~A} 1$ & 22 & 6 & 30 & 2 \\
\hline 17 & $\mathrm{~A} 1$ & 22 & 7 & 30 & 1 \\
\hline 18 & $\mathrm{~A} 1$ & 22 & 7 & 30. & 2 \\
\hline 19 & $\mathrm{Al}$ & 3 & 1 & 1 & 1 \\
\hline 20 & $\mathrm{Al}$ & 3 & 1 & 1 & 2 \\
\hline 21 & $\mathrm{Al}$ & 3 & 6 & 1 & 1 \\
\hline 22 & A1 & 3 & 6 & 1 & 2 \\
\hline 23 & A1 & 3 & 7 & 1 & 1 \\
\hline 24 & Al & 3 & 7 & 1 & 2 \\
\hline 25 & $\mathrm{Al}$ & 3 & 1 & 7 & 1 \\
\hline 26 & AI & 3 & 1. & 7. & 2 \\
\hline 27 & $\mathrm{AI}$ & 3 & 6 & 7 & 1 \\
\hline 28 & Al & 3 & 6 & 7 & 2 \\
\hline
\end{tabular}


TABLE 15 (Continued)

STAGNANT SEAWATER NUCLEATION TEST CONDITION

\begin{tabular}{|c|c|c|c|c|c|}
\hline $\begin{array}{c}\text { Tube } \\
\text { Sample }\end{array}$ & $\begin{array}{l}\text { Tube } \\
\text { Type }\end{array}$ & $\begin{array}{l}\text { Temperature } \\
\left({ }^{\circ} \mathrm{C}\right)\end{array}$ & $\frac{I M P}{K_{c}{ }^{\prime}}$ & $\begin{array}{c}\text { Exposure } \\
\text { (Days) }\end{array}$ & Replicate \\
\hline & & 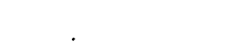 & . & & \\
\hline 29 & $\mathrm{~A} 1$ & 3 & 7 & 7 & 1 \\
\hline 30 & $\mathrm{~A} 1$ & 3 & 7 & 7 & 2 \\
\hline 31 & $\mathrm{Al}$ & 3 & 1 & 30 & 1 \\
\hline 321 & $\mathrm{~A} 1$ & 3 & 1 & 30 & 2 \\
\hline 33 & Al & 3 & 6 & 30 & 1 \\
\hline 34 & $\mathrm{Al}$ & 3 & 6 & 30 & 2 \\
\hline 35 & $\mathrm{~A} 1$ & 3 & 7 & 30 & 1 \\
\hline 36 & $\mathrm{Al}$ & 3 & 7 & 30 & 2 \\
\hline 37 & SS & 22 & 6 & 30 & 1 \\
\hline 38 & SS & 22 & 6 & 30 & 2 \\
\hline 39 & SS & 3 & 6 & 30 & 1 \\
\hline 40 & SS & 3 & 6 & 30 & 2 \\
\hline 41 & $\mathrm{Cu} / \mathrm{Ni}$ & 22 & 6 & 30 & 1 \\
\hline 42. & $\mathrm{Cu} / \mathrm{Ni}$ & 22 & 6 & 30 & 2 \\
\hline 43 & $\mathrm{Cu} / \mathrm{NI}$ & 3 & 6 & 30 & 1 \\
\hline 44 & $\mathrm{Cu} / \mathrm{Ni}$ & 3 & 6 & 30 & 2 \\
\hline 45 & $\mathrm{Ti}$ & 22 & 6 & 30 & 1 \\
\hline 46 & $\mathrm{Ti}$ & 22 & 6 & 30 & 2 \\
\hline 47 & $\mathrm{Ti}$ & 3 & 6 & 30 & 1 \\
\hline 48 & $\mathrm{Ti}$ & 3 & 6 & 30 & 2 \\
\hline $60^{4}$ & Al & 22 & 6 & 30 & 1 \\
\hline $61 *$ & $\mathrm{Cu} / \mathrm{Ni}$ & 22 & 6 & 30 & 1 \\
\hline $62 *$ & SS & 22 & 6 & 30 & 1 \\
\hline $63 *$ & $\mathrm{~T} i$ & 22 & 6 & 30 & 1 \\
\hline
\end{tabular}

*Etch cleaned and aged 


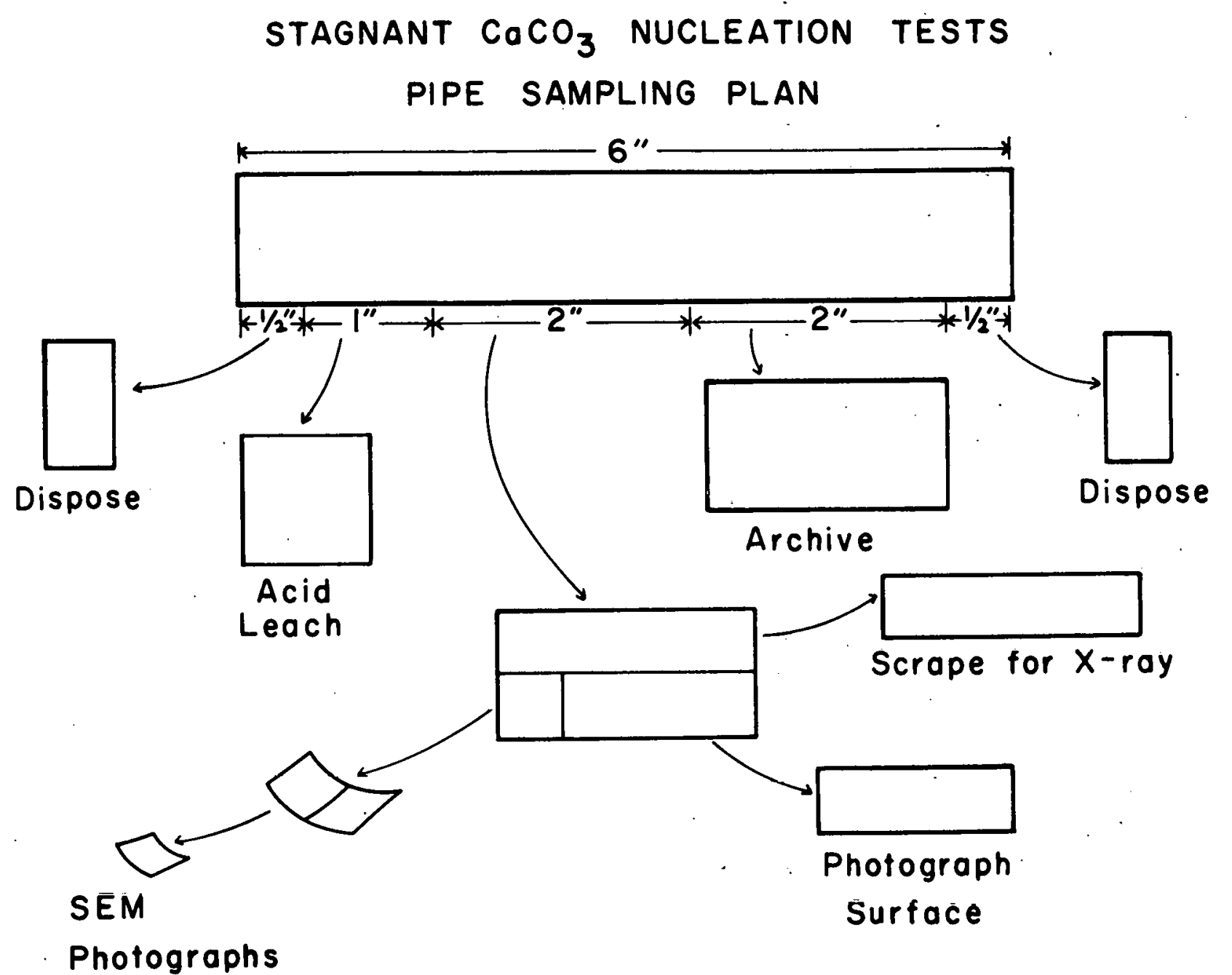

Figure 13. Stagnant $\mathrm{CaCO}_{3}$ nucleation tests pipe sampling plan 
Table 16

INITIAL IEST GULF STREAM SEAWATER CHEMISTRY

\begin{tabular}{|c|c|c|c|c|c|c|c|c|c|}
\hline $\begin{array}{c}\text { Salinity } \\
(\% / 00)\end{array}$ & $\begin{array}{c}A_{t} \\
(m e q / k g)\end{array}$ & $\begin{array}{c}\lambda_{c} \\
(\mathrm{meg} / \mathrm{kg})\end{array}$ & $\mathrm{pH}$ & $\begin{array}{c}{\left[\mathrm{Ca}^{++}\right]} \\
\left(\mathrm{mcles} / \mathrm{kg} \times 10^{3}\right)\end{array}$ & $\frac{\text { IMP }}{k_{c}^{\prime}}$ & $\begin{array}{c}\mathrm{NO}_{2} \\
(\mu \mathrm{g} \text { at } / \mathrm{l})\end{array}$ & $\begin{array}{c}\mathrm{NO}_{3} \\
(\mu \mathrm{g} \text { at } / \ell)\end{array}$ & $(\mu g$ at $/ \ell)$ & $(\mu \mathrm{g}$ at $/ \ell)$ \\
\hline 35.8 & 2.56 & 2.36 & 8.25 & 1.04 & 6.09 & 0.08 & 0.32 & 6.00 & 0.02 \\
\hline 35.8 & 2.73 & 2.55 & 8.28 & 1.04 & 7.06 & 0.03 & 0.32 & 6.00 & 0.02 \\
\hline 35.8 & 0.92 & 0.84 & 7.84 & 1.04 & 0.98 & 0.02 & 0.28 & 1.00 & $<0.01$ \\
\hline
\end{tabular}


TABLE 17

SEAWATER pH AND ALKALINITY AFTER 30-DAY EXPOSURE

\begin{tabular}{|c|c|c|c|c|c|c|c|}
\hline Tube & & $\mathrm{pH}$ & & $\Delta \mathrm{pH}$ & ${ }_{(\mathrm{meq} / \mathrm{kg})}^{\mathrm{A}_{\mathrm{t}}}$ & & $\begin{array}{c}\Delta A_{t} \\
(m e q / k g\end{array}$ \\
\hline 13 & & 7.81 & & -0.03 & 0.98 & & -0.06 \\
\hline 14 & & 7.89 & & -0.05 & 0.97 & & -0.05 \\
\hline 15 & & 7.89 & & -0.96 & 2.37 & & -0.19 \\
\hline 16 & & 7.89 & . & -0.96 & 2.35 & & -0.21 \\
\hline 17 & & 7.98 & & -0.30 & 2.44 & & -0.29 \\
\hline 18 & & 8.05 & $"$ & -0.23 & 2.31 & & -0.42 \\
\hline 31 & . & 8.55 & .. & +0.71 & 1.18 & & +0.26 \\
\hline 32 & & 8.57 & & +0.73 & 1.13 & & +0.21 \\
\hline 33 & & 8.84 & & +0.59 & 2.57 & & +0.01 \\
\hline 34 & 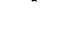 & 8.61 & & +0.36 & 2.59 & & +0.03 \\
\hline 35 & . & 8.65 & & +0.37 & 2.82 & & +0.09 \\
\hline 36 & & 8.65 & & +0.37 & 2.83 & . & +0.10 \\
\hline 37 & & 8.06 & & -0.19 & 2.45 & & -0.11 \\
\hline 38 & & 8.05 & & -0.20 & 2.44 & . & -0.12 \\
\hline 39 & & 8.51 & - & +0.26 & 2.55 & $\cdot$ & -0.01 \\
\hline 40 & & 8.51 & & +0.26 & 2.45 & . & -0.11 \\
\hline 41 & & 8.41 & & +0.16 & 1.76 & & -0.80 \\
\hline 42 & & 8.37 & & +0.12 & 2.40 & & -0.16 \\
\hline 43 & $\cdot$ & 8.83 & " & +0.58 & 2.64 & & +0.08 \\
\hline .44 & & 8.63 & & +0.38 & 2.54 & & -0.02 \\
\hline 45 & & 8.10 & & -0.15 & 2.43 & & -0.13 \\
\hline 46 & & 8.10 & & -0.15 & 2.40 & $\therefore$ & -0.16 \\
\hline 47 & & 8.52 & . & $+0: 27$ & 2.48 &. & -0.08 \\
\hline 48 & & 8.51 & & +0.26 & 2.49 & & -0.07 \\
\hline
\end{tabular}


TABLE 18

FINAL DISSOLVED METAL CONCENTRATIONS

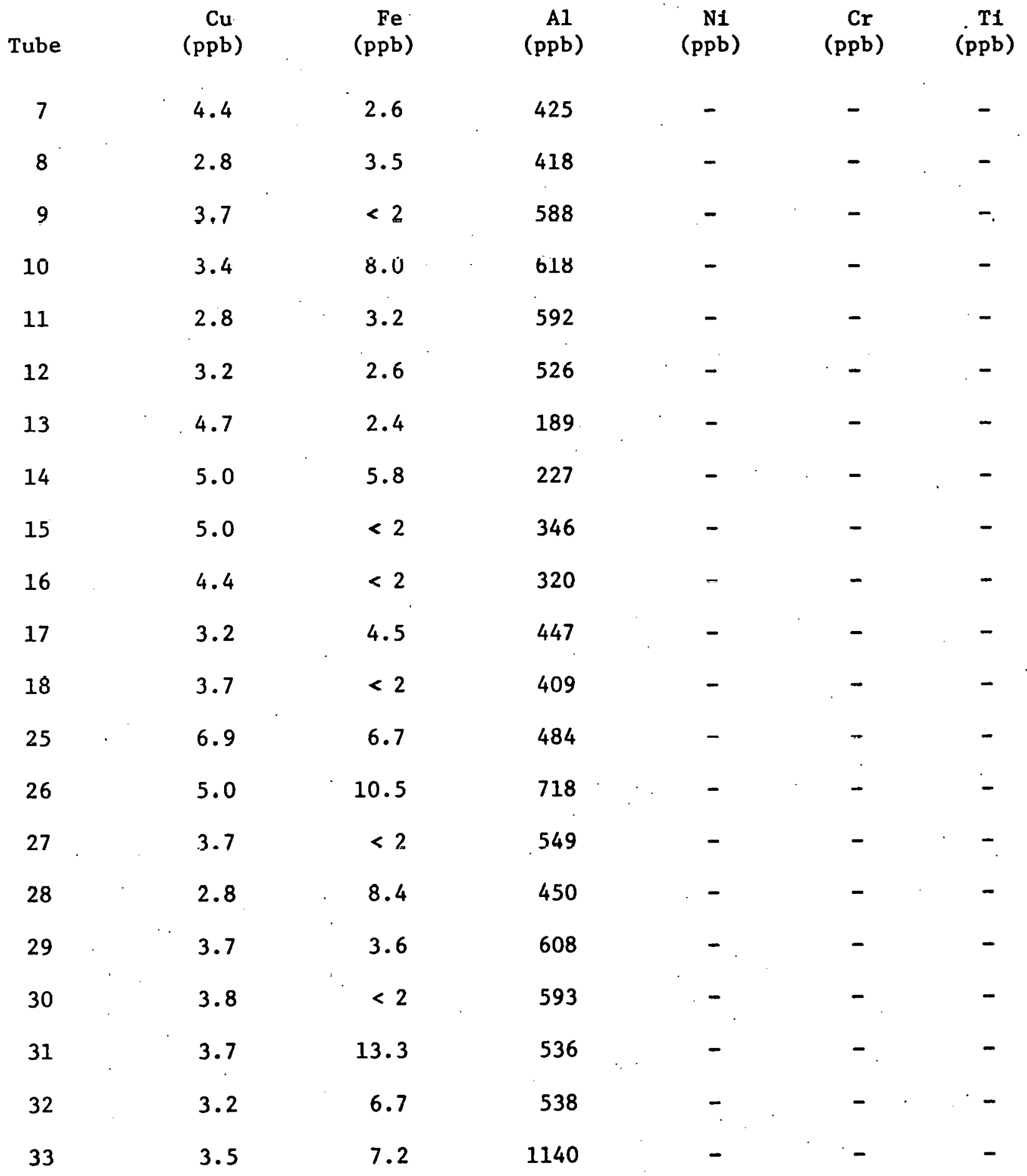


FINAL DISSOLVED METAL CONCENTRATIONS (Continued)

\begin{tabular}{|c|c|c|c|c|c|c|}
\hline Tube & $\begin{array}{c}\mathrm{Cu} \\
(\mathrm{ppb})\end{array}$ & $\begin{array}{c}F e \\
(\mathrm{ppb})\end{array}$ & $\begin{array}{c}\mathrm{Al} \\
(\mathrm{ppb})\end{array}$ & $\begin{array}{c}\mathrm{NI} \\
(\mathrm{ppb})\end{array}$ & $\begin{array}{c}\mathrm{Cr} \\
(\mathrm{ppb})\end{array}$ & $\begin{array}{c}\mathbf{T i} \\
(\mathrm{ppb})\end{array}$ \\
\hline 34 & 3.2 & $<2$ & 516 & - & - & - \\
\hline 35 & 4.4 & 6.2 & 713 & - & - & - \\
\hline 36 & 3.7 & 14.0 & 791 & - & - & - \\
\hline 37 & 6.0 & 6.0 & - & 65 & 6.5 & - \\
\hline 38 & 5.8 & 4.3 & - & 75 & 7.6 & - \\
\hline 39 & 8.9 & 6.7 & - & 66.5 & 6.5 & - \\
\hline 40 & 9.2 & 8.4 & - & 149.5 & 5.5 & - \\
\hline 41 & 5315 & 4.3 & - & 7875 & - & - \\
\hline 42 & 2350 & $<2$ & - & 4420 & - & - \\
\hline 43 & $2535^{\circ}$ & 25 & - & 6990 & - & - \\
\hline 44 & 3240 & 8.5 & - & 8060 & - & - \\
\hline 45 & 16.5 & $<2$ & - & - & - & $<50$ \\
\hline 46 & 12.6 & $<2$ & - & - & - & $<50$ \\
\hline 47 & 16.3 & 8.0 & - & - & - & $<50$ \\
\hline 48 & 14.2 & 18.5 & - & - & - & $<50$ \\
\hline
\end{tabular}


samples for 7 and 30 days are presented in Figure 14. After 7 days exposure all samples averaged between 500 and $600 \mathrm{ppb}$, except the samples stored at $22^{\circ} \mathrm{C}$ and initially in equilibrium with calcite, which averaged approximately $400 \mathrm{ppb}$. After 30 days of exposure all the samples stored at $22^{\circ} \mathrm{C}$ lost aluminum from solution, relative to the concentrations found after 7 days of exposure. The dissolved aluminum concentrations in the samples exposed to stagnant seawater for 30 days at $3^{\circ} \mathrm{C}$ showed a wide variation in concentrations with the average values generally being higher after 30 days exposure than after 7 days exposure. The highest dissolved metal concentrations were found in the seawater samples taken from the copper-nickel tubes after 30 days exposure. No significant differences are apparent in these samples between those stored at $3^{\circ} \mathrm{C}$ and $22^{\circ} \mathrm{C}$. The nickel concentrations average twice the copper concentrations in these samples. Relatively low trace netal concentrations were found in the samples from the titanium and stainless steel tube after 30 days exposure to stagnant seawater.

The absolute concentrations of inorganic scale components on tube surfaces are presented in Table 19. The concentration of aluminum scale, probably present as aluminum hydroxide, on the aluminum tube samples is significantly less than that found on the aluminum pipe surfaces, through which seawater was continuously flowing in the GOME II tests, but higher than on the aluminum pipe samples from the GOME II tests, which were exposed to stagnant seawater conditions after being exposed to flowing seawater conditions. The concentration of aluminum scale on aluminum tube surfaces, as a function of time, is presented in Figure 15 . The concentrations at $3^{\circ} \mathrm{C}$ are approximately two thirds those found at $22^{\circ} \mathrm{C}$. There is no significant dependence of aluminum scale concentration on the inilial saturation state of the seawater with respect to calcite. The concentrations of aluminum scale after 7 and 30 days exposure are similar. Approximately two thirds of the aluminum scale formed after only 1 day (or less) of exposure.

The highest concentrations of scale were found on the copper-nickel tubes exposed to seawater for 30 days. The copper plus nickel concentration on these samples averages approximately 3 times that of aluminum on aluminum tubes exposed to stagnant seawater for 30 days. The copper to nickel ratio in the scale is 9 to 1 , which is the same as their ratio in the host alloy. Only very minor scale concentrations were found on the stainless steel and titanium tube surfaces after 30 days exposure to stagnant seawater. The 
Figure 14. Dissolved Al concentrations in seawater exposed to Al tubes.

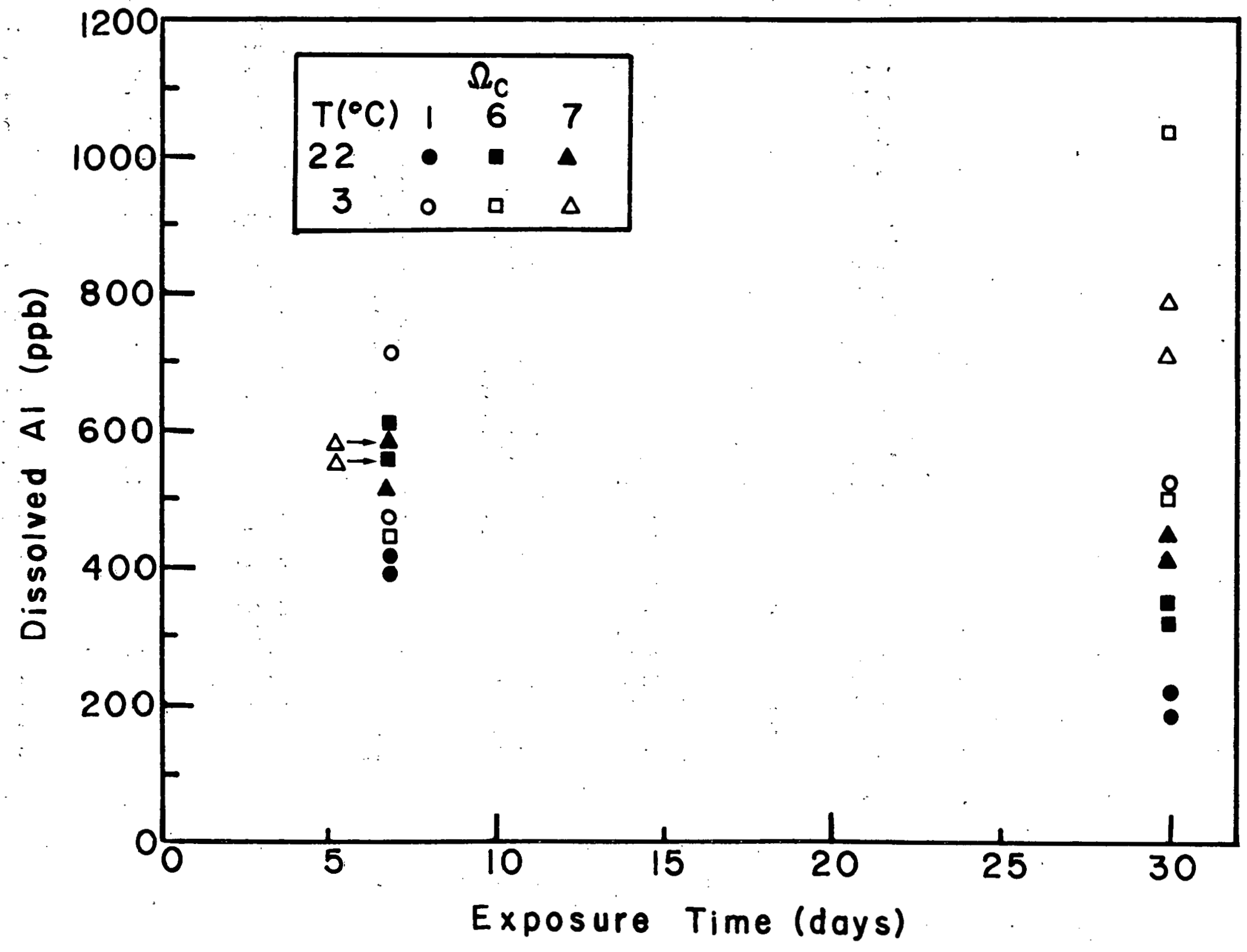


TABLE 19

TOTAE SURFACE CONCENTRATIONS*

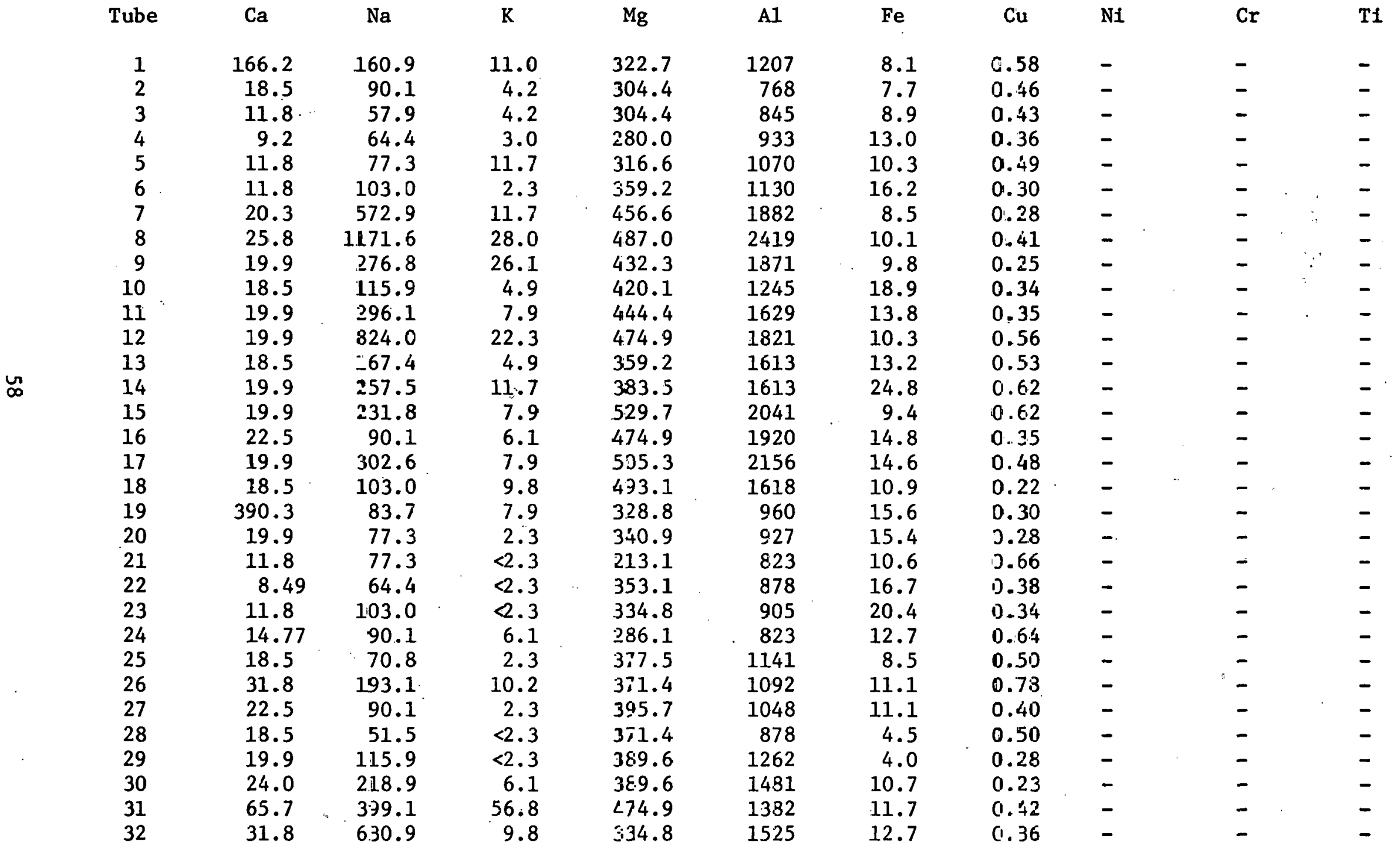


TABLE 19

TOTAL SURFACE CONCENTRATIONS*(Continued)

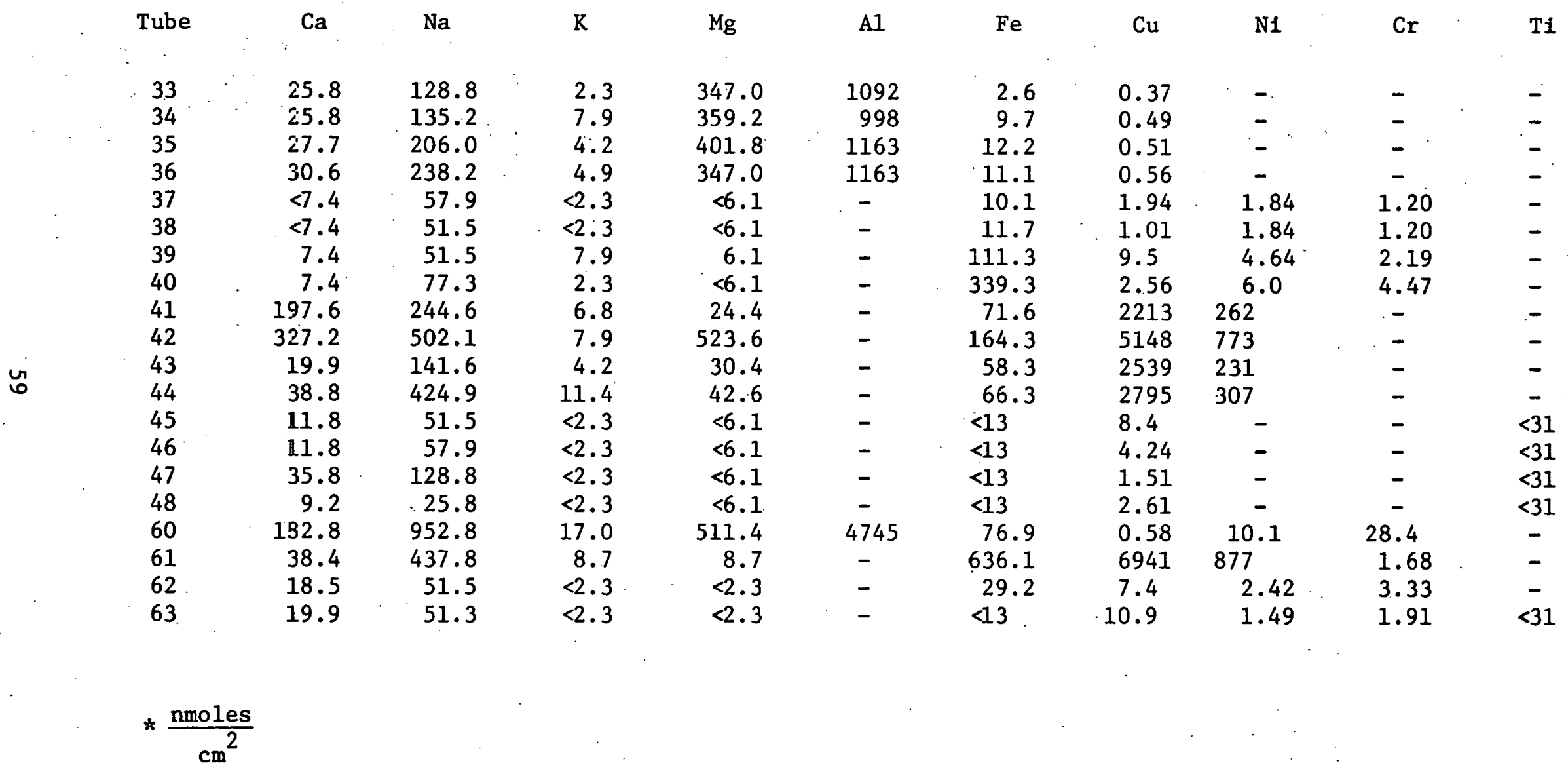


Figure 15. The concentration of $\mathrm{Al}$ on $\mathrm{Al}$ tube surfaces.

15 a exposure at $22^{\circ} \mathrm{C}$

$15 \mathrm{~b}$ exposure at $3^{\circ} \mathrm{C}$
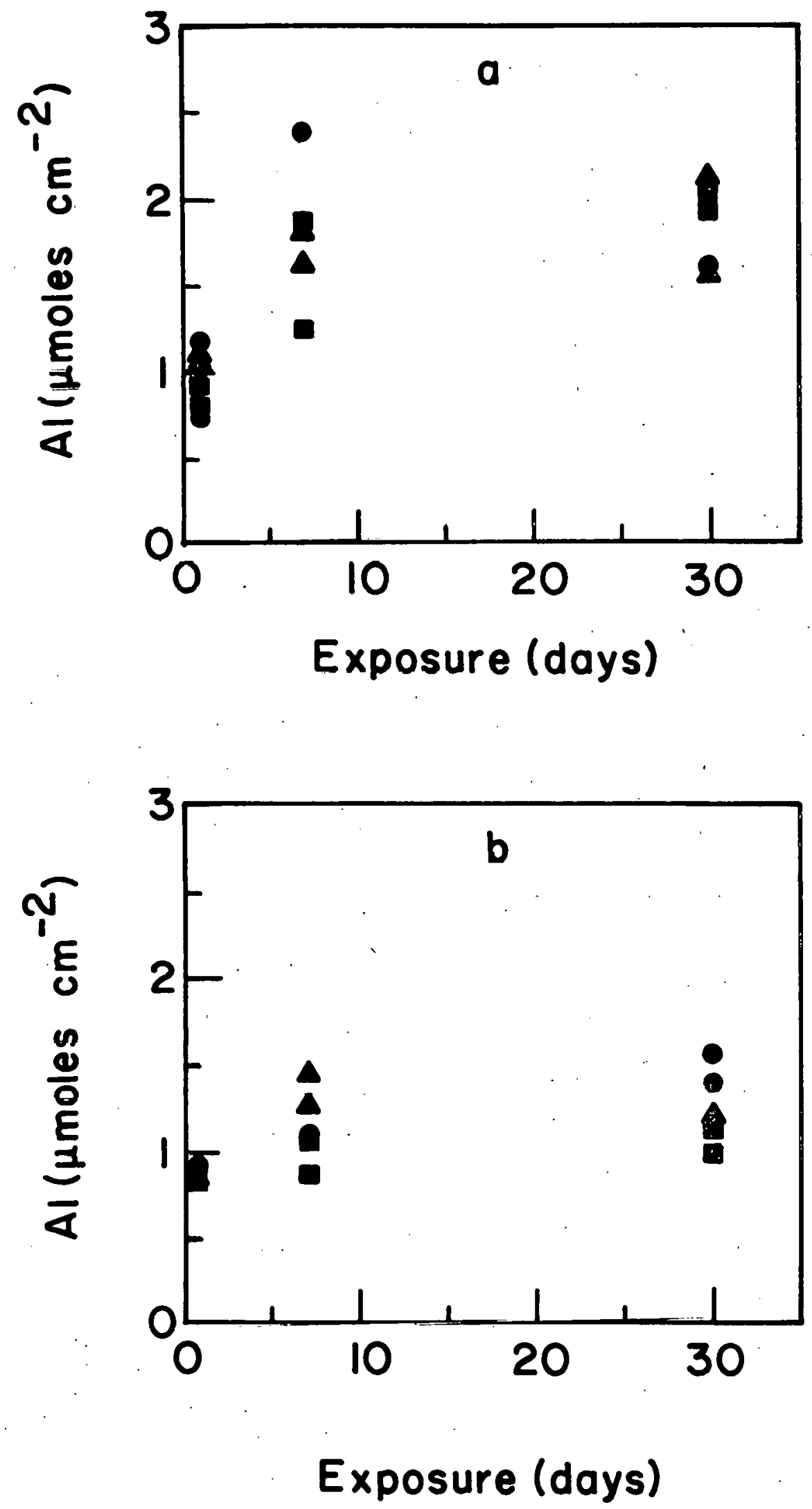
The average iron concentration on the stainless steel tubes exposed to stagnant seawater at $3^{\circ} \mathrm{C}$ was 20 times greater than on stainless steel tubes exposed to stagnant seawater at $22^{\circ} \mathrm{C}$. The concentration of scale components on the etched and "aged" tube samples are substantially higher on the aluminum and copper-nickel tubes. Unfortunately, these tube samples showed signs of seawater leakage during storage and the results should, consequently, not be given much significance.

Scanning electron photomicrographs of tube surfaces after tube exposure to seawater for 30 days at $22^{\circ} \mathrm{C}$, are presented in Figures 16 and 17 . The surfaces of the aluminum tubes are coated with a relatively smooth and homogeneous appearing corrosion product. Relic striations are present on the aluminum tube surfaces, even though the formation of the corrosion product layer has significantly smoothed the surfaces from their original rough condition. The distribution of corrosion products on the surfaces of the copper-nickel tubes is patchy. The patches of white material were scraped from the tube surface. They were identified by X-ray diffraction analysis to be either copper hydroxide chloride $\left(\mathrm{Cu}_{2}(\mathrm{OH})_{3} \mathrm{Cl}\right)$ or copper chloride 3 copper hydroxide $\left(\mathrm{CuCl}_{2} \cdot 3\left(\mathrm{Cu}(\mathrm{OH})_{2}\right)\right.$. The minor amounts of scale on the stainless steel and titanium tubes are relatively smooth and homogeneous in appearance. Some pits were found on the stainless steel tubes. It is uncertain if these pits were initially present or formed during exposure to seawater.

The sea salt corrected calcium and magnesium concentrations on tube surfaces are presented in Table 20. In Figure 18, the calcium and magnesium concentrations, and the magnesium to calcium concentration ratios on aluminum tube surfaces have been plotted as a lunction of exposure time. The concentration of calcium shows no strong correlation with time or initial saturation state of the seawater with respect to calcite. It does, however, show a temperature dependence, with the $3^{\circ} \mathrm{C}$ samples averaging $74 \%$ greater than the $22^{\circ} \mathrm{C}$ samples (neglecting samples 1 and 19 which appear to be spurious). The concentration of magnesium on the tube surfaces showed a slight increase with time, but no significant correlation with other tests variables.

The concentration of magnesium on the titanium and stainless steel tube surfaces can, within our analytical uncertainty, be entirely accounted for by sea sa1t. The concentration of calcium on thesc tube surfaces is also 

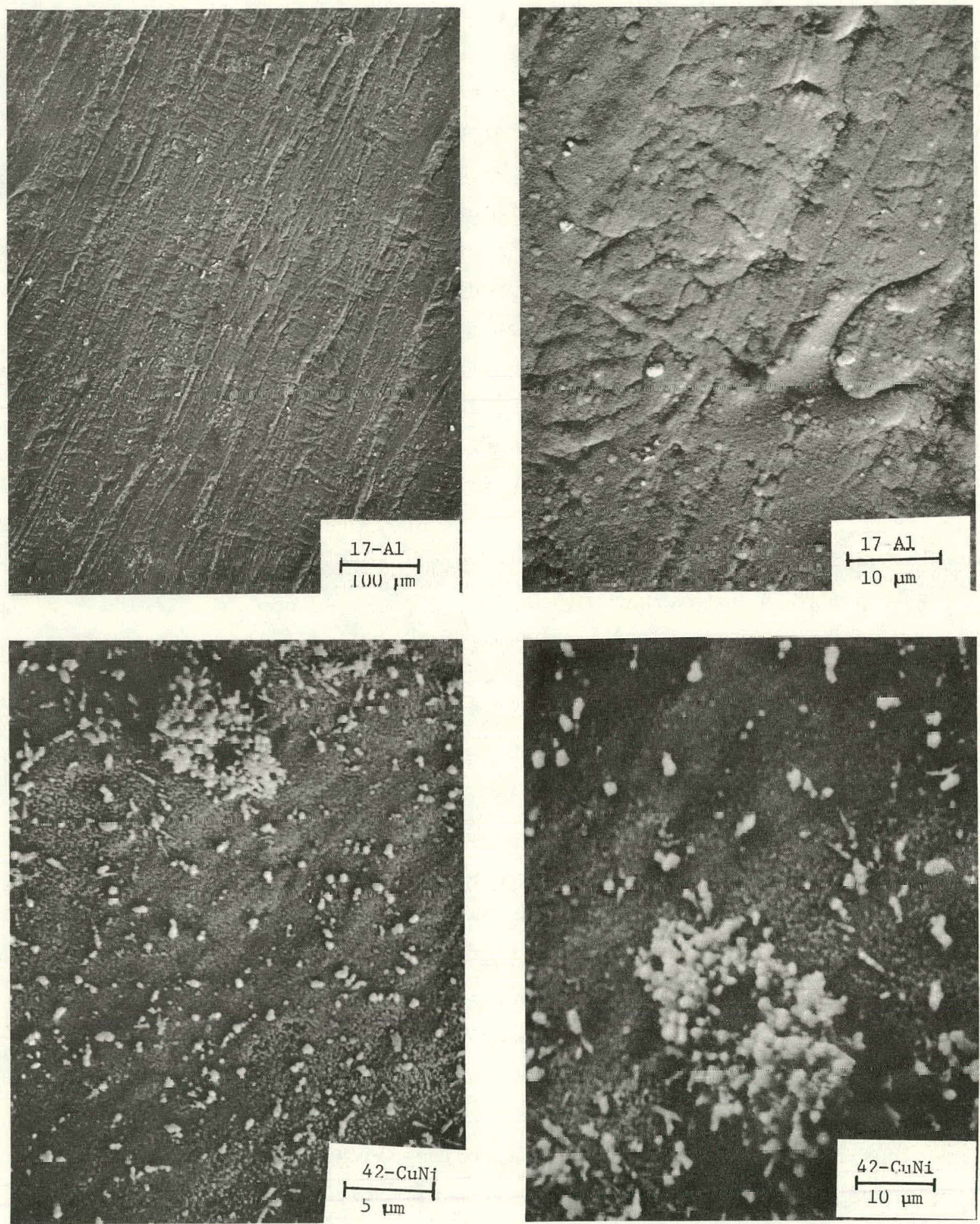

Figure 16. SEM pictures of $\mathrm{Al}$ and $\mathrm{Cu}-\mathrm{Ni}$ tube surfaces after exposure to stagnant seawater. 

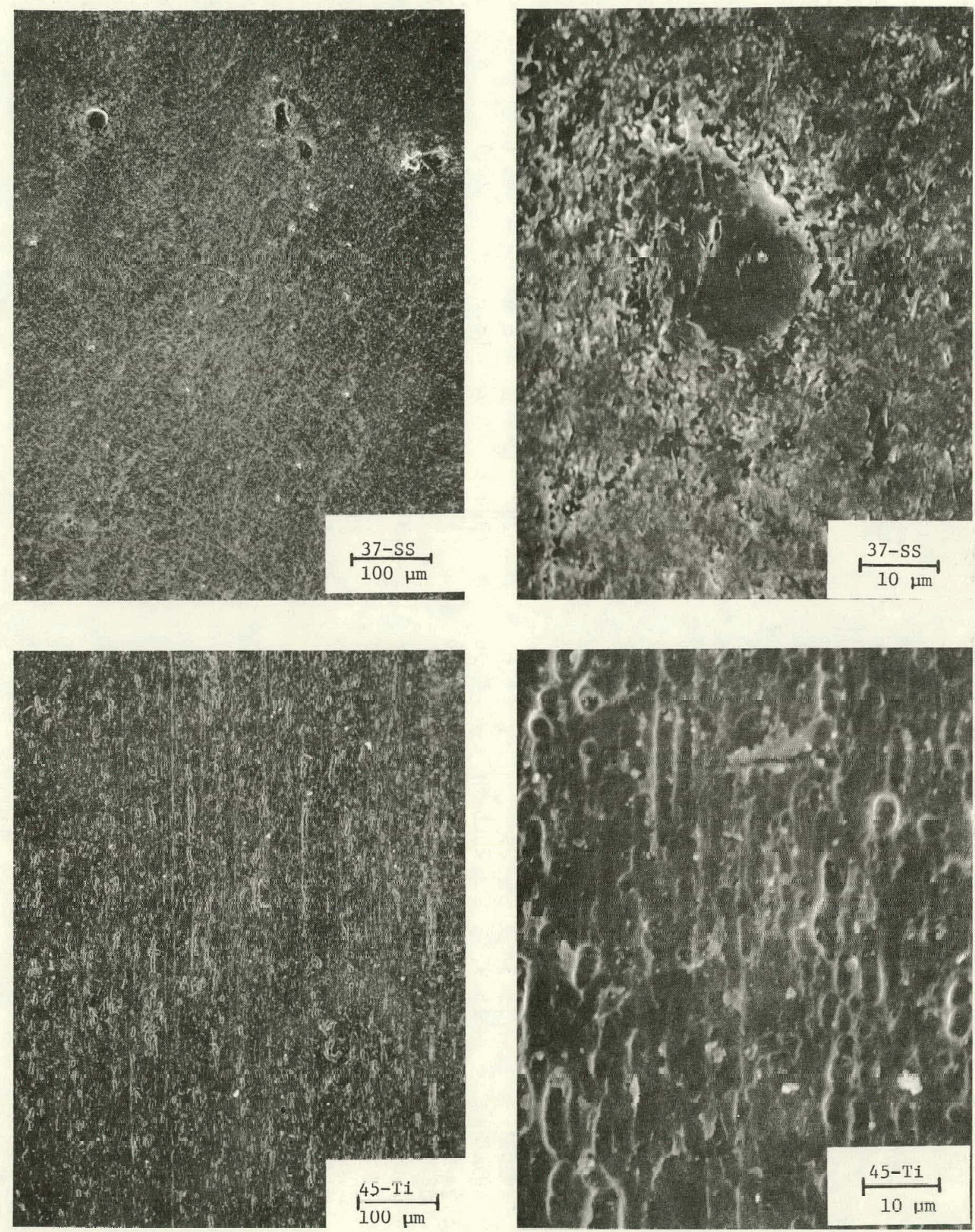

Figure 17. SEM pictures of SS and Ti tube surfaces after exposure to stagnant seawater. 
TABLE 20. SEA SA־T CORRECTED CALCIUM AND MAGNESIUM DATA

I

$\mathrm{Mg}_{\mathrm{Na}}$
304.6
294.3
297.9
272.7
307.9
347.6
392.1
355.1
401.1
407.04
411.1
382.1
340.4
354.5
503.6
464.8
471.2
481.5
319.4
332.2
204.4
345.8
323.2
275.95
369.5
349.7
385.6

$\mathrm{Ca}_{\mathrm{Na}}$

162.7

10.5

7.8

10.1

9.5

7.7

0.11

13.3

15.95

13.4

1.8

14.3

14.3

14.3

20.5

13.3

16.2

388.5

18.2

10.1

7.1

9.5

12.3

16.9

27.5

20.5

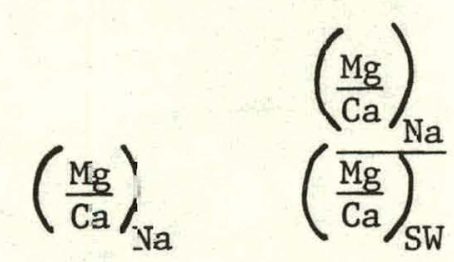

1.37
17.3
28.3
35
30.5
36.4
50.5

2995.7

29

25.5

30.7

207.7

22.7

24.7

33.97

22.5

35.5

29.5

0.3

18.2

20.2

48.9

33.7

21.6

21.8

12.7

18.8

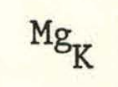

0.36

3.5

5.5

6.8

5.9

7.1

9.9

582.9

5.6

4.96

5.96

40.5

4.5

4.8

6.6

4.4

6.9

5.8

0.2

3.6

3.9

9.5

6.6

4.2

4.2

2.5

3.7

265.8

282.7

282.7

264.5

256.1

347.3

396.1

342.2

297.3

394.8

403.5

359.5

333.9

322.97

488.8

443.3

464.4

442.4

287.9

329

213.1

353.1

334.8

254.5

365.6

318.6

383.8

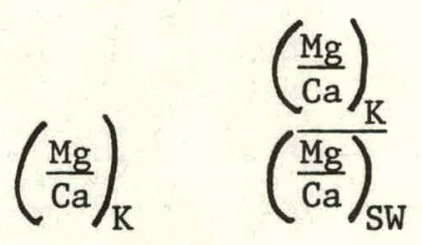

\begin{tabular}{|c|c|c|}
\hline $\mathrm{Ca}_{\mathrm{K}}$ & $\mathrm{Ca} \int_{\mathrm{K}}$ & $\left.\frac{\mathrm{Mg}}{\mathrm{Ca}}\right)$ \\
\hline 155.1 & 1.71 & 0.33 \\
\hline 14.3 & 19.8 & 3.8 \\
\hline 7.6 & 37.3 & 7.3 \\
\hline 6.2 & 42.8 & 8.3 \\
\hline 0.01 & 1414.78 & 2753.03 \\
\hline 9.5 & 36.7 & 7.1 \\
\hline 8.5 & 46.5 & 9.04 \\
\hline-2.4 & -142.8 & -27.8 \\
\hline-6.4 & $-\quad 46.6$ & $-\quad 9.1$ \\
\hline 13.6 & 29.1 & 5.7 \\
\hline 11.9 & 33.8 & 6.6 \\
\hline-2.6 & -140.7 & -27.3 \\
\hline 13.6 & 24.6 & 4.8 \\
\hline 8.1 & 39.8 & 7.7 \\
\hline 11.9 & 40.9 & 7.96 \\
\hline 16.3 & 27.1 & 5.3 \\
\hline 11.9 & 38.9 & 7.6 \\
\hline 8.6 & 51.3 & 9.97 \\
\hline 382.3 & 0.8 & 0.1 \\
\hline 17.6 & 18.7 & 3.6 \\
\hline 11.3 & 18.1 & 3.5 \\
\hline 8.5 & 41.6 & 8.1 \\
\hline 11.8 & 28.4 & 5.5 \\
\hline 8.6 & 29.5 & 5.7 \\
\hline 16.2 & 22.6 & 4.4 \\
\hline 21.5 & 14.8 & 2.9 \\
\hline 20.2 & 19.0 & 3.7 \\
\hline
\end{tabular}


TABLE 20. SEA SALT CORRECTED CALCIUM AND MAGNESIUM DATA (Continued)

\begin{tabular}{|c|c|c|c|c|c|c|c|c|}
\hline Tube & $\mathrm{Mg}_{\mathrm{Na}}$ & ${ }^{\mathrm{Ca}} \mathrm{Na}$ & $\left(\frac{\mathrm{Mg}}{\mathrm{Ca}}\right)_{\mathrm{NA}}$ & $\left(\frac{\overline{\mathrm{Mg}}}{\mathrm{Ca}}\right)_{\mathrm{SW}}$ & $\mathrm{Mg}_{\mathrm{K}}$ & $\mathrm{Ca}_{\mathrm{K}}$ & & \\
\hline 28 & 365.6 & 17.4 & 21.0 & 4.1 & 371.4 & 18.5 & 20.1 & 3.9 \\
\hline 29 & 376.5 & 17.4 & 21.7 & 4.2 & 389.6 & 19.9 & 19.6 & 3.8 \\
\hline 30 & 364.95 & 19.2 & 19 & 3.7 & 358 & 17.9 & 20.1 & 3.9 \\
\hline 31 & 429.96 & 56.95 & 7.5 & 1.5 & 181.1 & 8.5 & 21.3 & 4.1. \\
\hline 32 & 263.8 & 18 & 14.7 & 2.9 & 284.1 & 21.9 : & 13 & 2.5 \\
\hline 33 & 332.5 & 23 & 14.5 & 2.8 & 335.1 & 23.5 & 14.3 & 2.8 . \\
\hline 34 & 344 & 22.9 & 15.1 & 2.9 & 318.3 & 17.8 & 17.8 & 3.5 \\
\hline 35 & 378.6 & 23.2 & 16.3 & 3.2 & 380.1 & 23.5 & 16.2 & 3.2 \\
\hline 36 & 320.2 & 25.4 & 12.6 & 2.5 & 321.7 & 25.7 & 12.5 & 2.4 \\
\hline 37 & -6.5 & -1.3 & 5.1 & 1 & 0 & 0 & 1 & 0.2 \\
\hline 38 & -5.8 & -1.1 & 5.1 & 1 & 0 & 0 & 1 & 0.2 \\
\hline 39 & 0.3 & 6.3 & 0.04 & 0.009 & -34.8 & -0.5 & 62.6 & 12.2 \\
\hline 40 & -8.7 & 5.7 & -1.5 & -0.3 & -11.9 & 5.1 & -2.3 & -0.5 \\
\hline 41 & -3.1 & 192.2 & -0.01 & 0 & -10.1 & 190.8 & -0.1 & -0.01 \\
\hline 42 & 467.1 & 316.2 & 1.5 & 0.3 & 482.7 & 319.2 & 1.5 & 0.3 \\
\hline 43 & 14.4 & 16.8 & 0.9 & 0.2 & 8.7 & 15.7 & 0.6 & $\therefore \quad 0.1$ \\
\hline 44 & -5.2 & 29.5 & -0.2 & -0.03 & -16.4 & $27.3^{\circ}$ & -0.6 & -0.1 \\
\hline 45 & -5.8 & 10.7 & -0.5 & -0.1 & 0 & 11.8 & 0 & 0 \\
\hline 46 & -6.5 & 10.5 & -0.6 & -0.1 & 0 & 11.8 & 0 & 0 \\
\hline 47 & -14.5 & 33 & -0.4 & -0.1 & 0 & 35.8 & 0 & 0 \\
\hline 48 & -2.9 & 8.6 & -0.3 & -0.1 & - & 9.2 & 0 & 0 \\
\hline 60 & 404.1 & 161.9 & 2.5 & 0.5 & 423.5 & 165.7 & 2.6 & 0.5 \\
\hline 61 & 60.3 & 28.8 & 2.1 & 0.4 & 64.6 & 29.6 & 2.2 & 0.4 \\
\hline 62 & 30.7 & 17.4 & 1.8 & 0.34 & 36.5 & 18.5 & 2.0 & 0.4 \\
\hline 63 & 24.6 & 18.8 & 1.3 & 0.3 & 30.4 & 19.9 & 1.5 & 0.3 \\
\hline
\end{tabular}




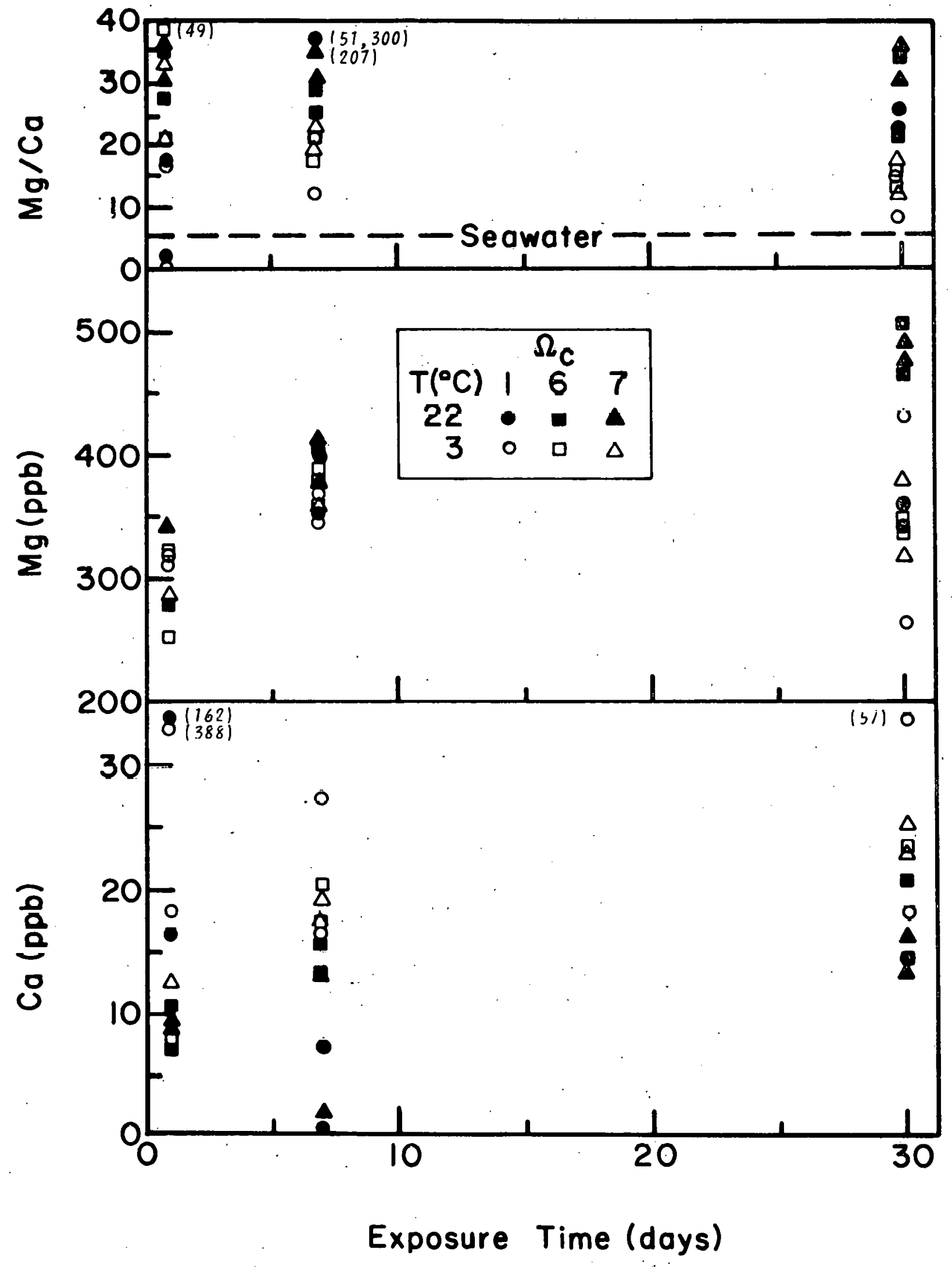

Figure 18. Calcium and magnesium on Al tube surfaces. 
very close to that which can be accounted for by sea salt. With the exception of one sample, the magnesium concentrations on the copper-nickel tubes are very low. The concentration of calcium on the copper-nickel tubes exposed to stagnant sewater at $3^{\circ} \mathrm{C}$ is similar to that generally found on the aluminum tube surfaces. The concentration of calcium on the copper-nickel tube surfaces exposed to stagnant seawater at $22^{\circ} \mathrm{C}$ is approximately 10 times higher than generally found on the aluminum tubes. These high calcium concentrations may be indicative of calcium carbonate formation. We were, however, unable to substantiate the presence of calcium carbonate by $\mathrm{X}$-ray diffraction analysis.

\section{ACKNOWLEDGEMENTS}

The authors thank Breanda Little, Tony Mendez, Cindy Moore, Alfonso Mucci, Sara Sotolongo and Catherine Tuttle for their assistance in the project. 


\section{BIBLIOGRAPHY}

Berner, R. A., 1975. The role of magnesium in the crystal growth of calcite and aragonite from seawater, Geochim. Cosmochim. Acta, 39: 489-504.

de Kanel, J. and J. W. Morse, 1979. A simple technique for surface area determination, J. Phys. E: Sci. Instrum., 12(4): 272-273.

Ingle, S. E., 1975. Solubility of calcite in the ocean, Mar. Chem., 3: $\quad 301-319$.

Kalz, A., E. Suess, A. Slarinsky and H. D. Holländ, 1972. Strontium behavior in the aragontte-calctte transformation: An experimental study at $40-98^{\circ} \mathrm{C}$, Geochim. Cosmochim. Acta, 36, 481-496.

Lyman, J., 1957. Buffer mechanism of sea water, Ph.D. Thesis, University of California, Los Angeles, $196 \mathrm{pp}$.

Mehrbach, C., C. H. Culberson, J. E. Hawley and R. M. Pytkowicz, 1973. Measurement of the apparent dissociation constants of carbonic acid in seawater at atmospheric pressure, Limnol. Oceanogr., 18: 897-907.

Millero, F. J. and J. W. Morse, 1979. The carbonate system in seawater, In: CRC Handbook Series of Biosolar Resources, Vol. I, Basic Principles, C. C. Black and A. Mitsui (eds.), CRC Press, West Palm Beach, Florida (Submitted).

Moroc, J. W., 1974. Diccolution kinetice of calcium carbonate in sea water. III. A new method for the study of carbonate reaction kinetics, Am. J. Sci., 274: 97-107.

Morse, J.W., 1978. Dissolution kinetics of calcium carbonate in sea water: VI. The near-equilibrium dissolution kinetics of calcium carbonate-rich deep sea sediments, Am. J. Sci., 278: 344-353.

Morse, J. W. and H. L. Craig, Jr., 1978. Test procedures to define the ranges of balance between dissolved $\mathrm{CO}_{2}$ and carbonates in seawater that could lead to deposition of calcareous deposits on heat transfer surfaces within the temperature range nf nTFi, heat exchangers, Final Report to Department of Energy, Contract No. EY-76-C-06-2830; Pacific Northwest Laboratories, Battelle Memorial Institute, Special Agreement No. B-07455-A-E, 35 pp. 
Morse, J. W., A. Mucci and F. J... Millero, 1979.' The solubility of calcite and aragonite in seawater of $35^{\circ} \%$ salinity at $25^{\circ} \mathrm{C}$ and atmospheric pressure, Geochim, Cosmochim. Acta (Submitted).

Schrieber, C. F., W. D. Grimes, and W. F. McIlhenny, 1979. A study of the corrosive effect on aluminum and CP titanium of mixtures of ammonia and seawater that may be encountered in OTEC heat exchangers, Argonne National Laboratory, ANL/OTEC-BCM-004, 1979.

Segar, D. A. and A. Y. Cantil1o, 1975. Direct determination of trace metals in seawater by flameless atomic absorption spectrophotometry, In: Analytic Methods in Oceanography, T.R.P. Gibb, Jr. (ed.), American Chemical Society, Washington D. C., 56-81.

Strickland, J.D.H. and T. R. Parsons, 1972. A Practical Handbook of Seawater Analysis, Fish. Research Board Canada, 49-52.

Weiss, R. F., 1974. Carbon dioxide in water and seawater: the solubility of a non-ideal gas, Mar. Chem., 2: 203-215.

Wray, J. L. and F. Daniels, 1957. Precipitation of calcite and aragonite, J. Am. Chem. Soc., 79: 2031-2034. 
Distribution for ANL/OTEC-BCM-006

Internal:

P. H. Benson

G. F. Popper

J. B. Darby, Jr.

J. J. Roberts

J. D. Ditmars

J. E. Draley (5)

N. F. Sather

B. R. T. Frost

A. Thomas

A. P. Gavin

A. B. Krisciunas

ANL Contract File

ANL Libraries (5)

TIS Files (6)

\section{Externa1:}

DOE-TIC, for distribution per UC-64 (423)

Manager, Chicago Operations and Regional office, DOE

Chief, Office of Patent Counsel, DOE-CORO

President, Argonne Universities Association

$\mathrm{J}$. Hilbert Anderson, Sea Solar Power, Inc.

M. Kent Anderson, Trane Air Conditioning

Takaaki Anzai, Florida Institute of Technology

W. H. Avery, Applied Physics Laboratory, Johns Hopkins Universicy

E. Barsness, Westinghouse Electric Corporation, Lester, PA

James 0. Bates, Energy Technology Engineering Center

Kenneth J. Bell, Oklahoma State University

Robert A. Bonewitz, Aluminum Company of America

Garrett W. Brass, University of Miami

R. Cohen, US-DOE, Div. of Central Solar Technology

William A. Corpe, Columbia University

R. S. Dalrymple, Reynolds Metals Company, Richmond, VA

G. J. Danek, Annapolis, Maryland

James Denton, TRW Systems and Energy, Redondo Beach, CA

John DePalma, U. S. Naval Oceanographic Office

Stephen Dexter, University of Delaware

John G. Fetkovich, Carnegle-Mellon University

Harry Foust, Trane Air Conditioning

Malcom D. Fraser, Intertechnology Corporation

John Gertz, Westinghouse Electric Corporation, Lester, PA

Sigmund Gronich, US-DOE, Div. of Central Solar Technology

T. II. Iladley, Jr., Gibbs \& Cox, Inc.

L. W. Hallanger, Research Corporation, University of Hawaii

William Hartt, Florida Atlantic University

William E. Heronemus, University of Massachusetts

F. K. Hill, Applied Physics Laboratory, Johns Hopkins University

Jules Hirshman, NYIT Research Center, Dania, FL

J. F, Jenkins, Civil Engineering Laboratory

E. H. Kinelski, US-DOE, Div. of Central Solar Technology

Robert E. Lacey, Southern Research Institute

F. L. LaQue, Verona, New Jersey

Abrahim Lavi, Carnegie-Mellon University

T. S. Lee, International Nickel Company, Wrightsville Beach, NC

Murray Leitner, Lockheed Missiles and Space Co., Inc., Sunnyvale, CA

Lloyd Lewis, US-DOE, Div. of Central Solar Technology

Brenda Little, NORDA

D. Lott, Naval Coastal Systems Center 
Richard N. Lyon, Oak Ridge National Laboratory

Frank Mathews, Colorado School of Mines

John W. Miche1, Oak Ridge National Laboratory

Ralph Mitchel1, Harvard University

Robert L. Molinari, NOAA/AMOL

John Morse, University of Miami (2)

R.S.C. Munier, Tracor Marine, Port Everglades, FL

John Nicol, Arthur D. Little, Inc.

Merle Olmsted, General Electric Company, Schenectady, NY

T. B. O'Neill, Civil Engineering Laboratory

Steven Pohlman, Solar Energy Research Institute

David Price, U. S. National Oceanic \& Atmospheric Administration

W. W. Pritsky, Aluminum Association

J. F. Rynewicz, Lockheed Missiles and Space Co., Inc., Sunnyvale, CA

Donald Sasscer, University of Puerto Rico

C. F. Schrieber, Dow Chemical Company, Freeport, TX

H. H. Sephton, University of California at Berkeley

B. Shelpuk, Solar Energy Research Institute

William Sheppard, NOAA Data Buoy office

J. E. Snyder, TRW Systems and Energy, Redondo Beach, CA

Frank Spiehler, NOAA Data Buoy Office

T. J. Summerson, Kaiser Aluminum and Chemical Corp., Pleasanton, CA

R. B. Teel, Chatham, New Jersey

D. L. Thomas, Charles T. Main, Inc.

Reed Van Valin, University of Miam1

Fred Vukovich, Research Triangle Institute

J. Paul Walsh, Value Engineering Company

Lynn M. Walter, University of Miami

E. T. Wanderer, Aluminum Company of America

Ralph L. Webb, Pennsylvania State University

Pat Wilde, University of California at Berkeley

Ralph Williams, PRC Energy Analysis Co.

David C. White, Florida State University

Hank White, Natural Energy Laboratory of Hawail

Clarence Zener, Carnegie-Mellon University 